INTER NATIONAL MONETARY FUND

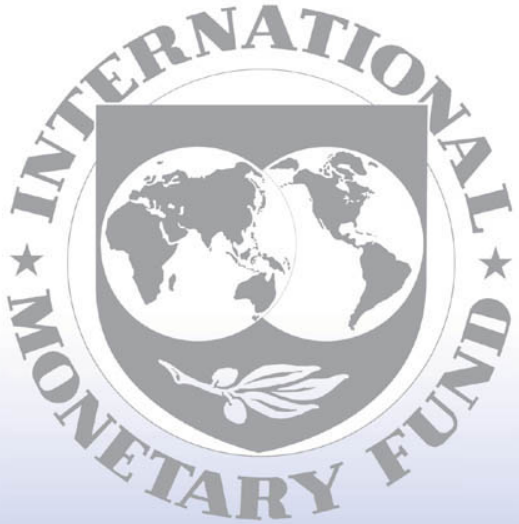

Staff

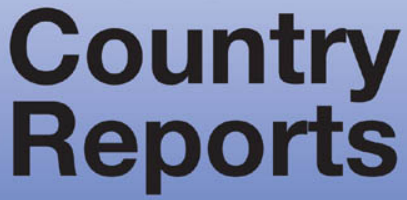




\section{Republic of Poland: Financial Sector Assessment Program- Technical Note-Credit, Growth, and Financial Stability}

This Technical Note on Credit, Growth, and Financial Stability for the Republic of Poland was prepared by a staff team of the International Monetary Fund as background documentation to the Financial Sector Assessment Program with the member country. It is based on the information available at the time it was completed in October 2006. The views expressed in this document are those of the staff team and do not necessarily reflect the views of the government of the Republic of Poland or the Executive Board of the IMF.

The policy of publication of staff reports and other documents by the IMF allows for the deletion of market-sensitive information.

To assist the IMF in evaluating the publication policy, reader comments are invited and may be sent by e-mail to publicationpolicy@imf.org.

Copies of this report are available to the public from

International Monetary Fund • Publication Services

700 19th Street, N.W. • Washington, D.C. 20431

Telephone: (202) 6237430 • Telefax: (202) 6237201

E-mail: publications@imf.org • Internet: http://www.imf.org

Price: $\$ 18.00$ a copy

\section{International Monetary Fund Washington, D.C.}


This page intentionally left blank 
FinANCIAL SECTOR ASSESSMENT PROGRAM UPDATE REPUBLIC OF POLAND

TECHNICAL NOTE

CREDIT, GROWTH, AND

FINANCIAL STABILITY

OCTOBER 2006

INTERNATIONAL MONETARY FUND MONETARY AND CAPITAL MARKETS DEPARTMENT
THE WORLD BANK FinANCIAL AND PRIVATE SECTOR DEVELOPMENT VICE PRESIDENCY EuRoPe \& Central Asia Region Vice Presidency 


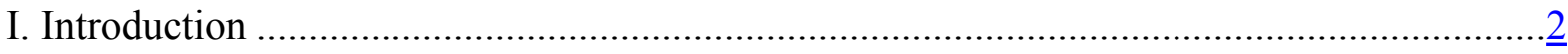

II. Why Has Credit Growth Been So Slow? ........................................................................

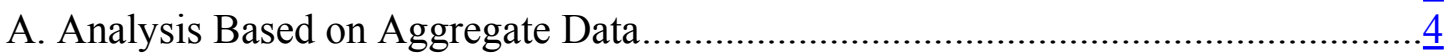

B. Analysis Based on Bank-Level Data.................................................................12

III. Is Rapid Growth of Foreign Currency Housing Lending a Concern for Financial Stability?

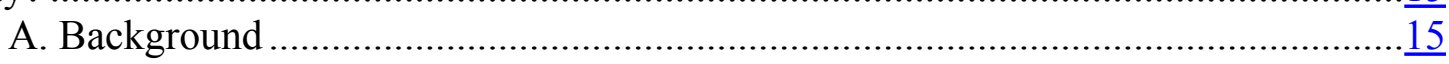

B. Analysis of Risks Associated with Foreign Currency Housing Lending .................

IV. Policy Response to Rapid Growth of Foreign Currency Credit .......................................29

A. Lessons from Cross-Country Experiences .............................................................29

B. Policy Response in Poland ...............................................................................29

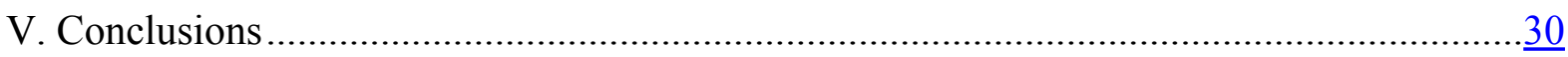

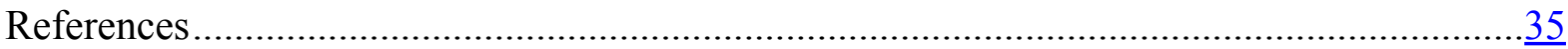

Tables

1. Poland: Modeling Growth of Credit to the Private Sector.................................................11

2. Credit Growth in Poland Compared to Other New Member States,. 1995-2004 .................13

3. Poland: Financial Soundness Indicators for the Banking Sector, 1998-2005 ......................21

4. Modeling the Probability of Default on Corporate and Household Bank Loans in Poland 24

5. Modeling Credit Growth and Bank Soundness in Poland, 2001-04 ..................................28

Figures

1. Poland: Growth of Credit to the Private Sector, 1998-2006

2. Poland: Composition of Credit to the Private Sector, 1996-2006 ……...................................

3. Poland: Private Sector Credit and Macroeconomic Environment, 1997-2005 .......................

4. Poland: Demand and Supply Factors Driving Private Sector Credit, 1997-2005.................10

Boxes

1. Distance to Default as a Summary Measure of Bank Soundnes.

2. How Experiences in Home Countries Have Affected Foreign Banks' Strategies for Foreign Currency Mortgage Lending in the NMS

Appendix

Country Experience with Measures to Address Risks 


\section{INTRODUCTION}

1. Two main issues at the interface between economic growth and financial stability are germane to this year's Article IV consultation and the FSAP Update:

The first is why the recent pace of financial catching-up has been so much slower in Poland than in its regional peers, and whether this might hamper Poland's long-term economic prospects. In a country like Poland, private sector credit can be expected to grow faster than GDP, as bank intermediation rises to levels consistent with Poland's level of economic development and other country characteristics. Yet, following a period of rapid expansion in the 1990s, lending to the private sector came to a standstill in the early $2000 \mathrm{~s}$. Since then, nominal private sector credit has been growing only marginally faster than nominal GDP - the lowest rate among new member states of the European Union (NMS), ${ }^{1}$ comparable to that in countries with much more developed financial systems. Although private sector credit started to recover in recent quarters, the overall pace of financial deepening remains subdued.

Financial Deepening in Selected Countries, 2001-05

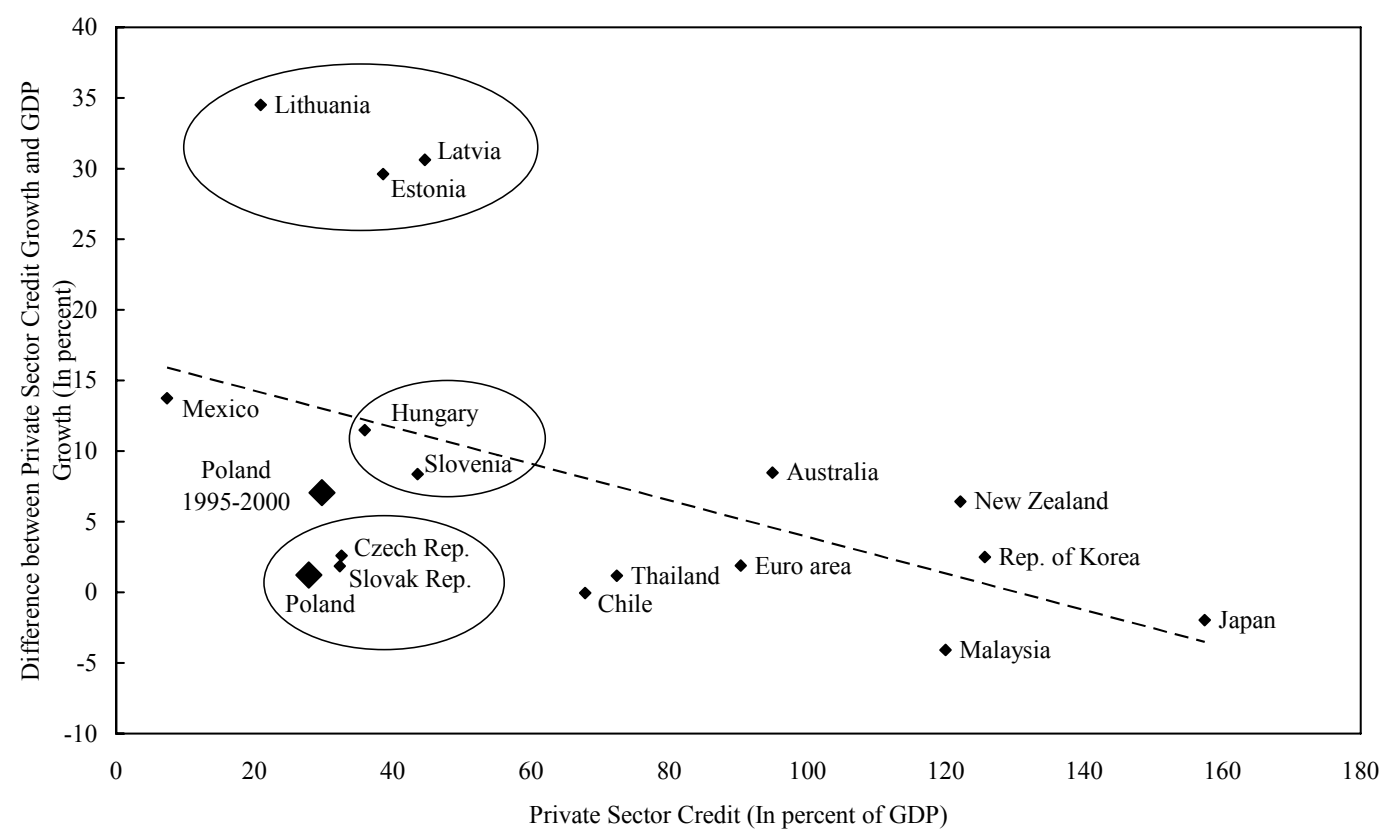

Sources: National central banks; the IMF's International Financial Statistics; and IMF staff estimates.

The second question is how significant the prudential risks associated with rapid growth in housing loans are. The low figures on total credit growth mask significant differences in the dynamics of corporate and household credit: corporate lending has been subdued in recent years, while household credit has been expanding briskly.

\footnotetext{
${ }^{1}$ The eight central and eastern European countries that joined the European Union (EU) in May 2004: the Czech Republic, Estonia, Hungary, Latvia, Lithuania, Poland, the Slovak Republic, and Slovenia.
} 
Housing loans to households, in particular, grew at an average annual rate of close to 40 percent in the last four years. Moreover, about two thirds of these loans have been indexed to foreign currency — one of the highest shares in Europe and among the NMS.

Foreign Currency Housing Loans to Households in Selected Countries, 2005

(In percent of total housing loans to households)

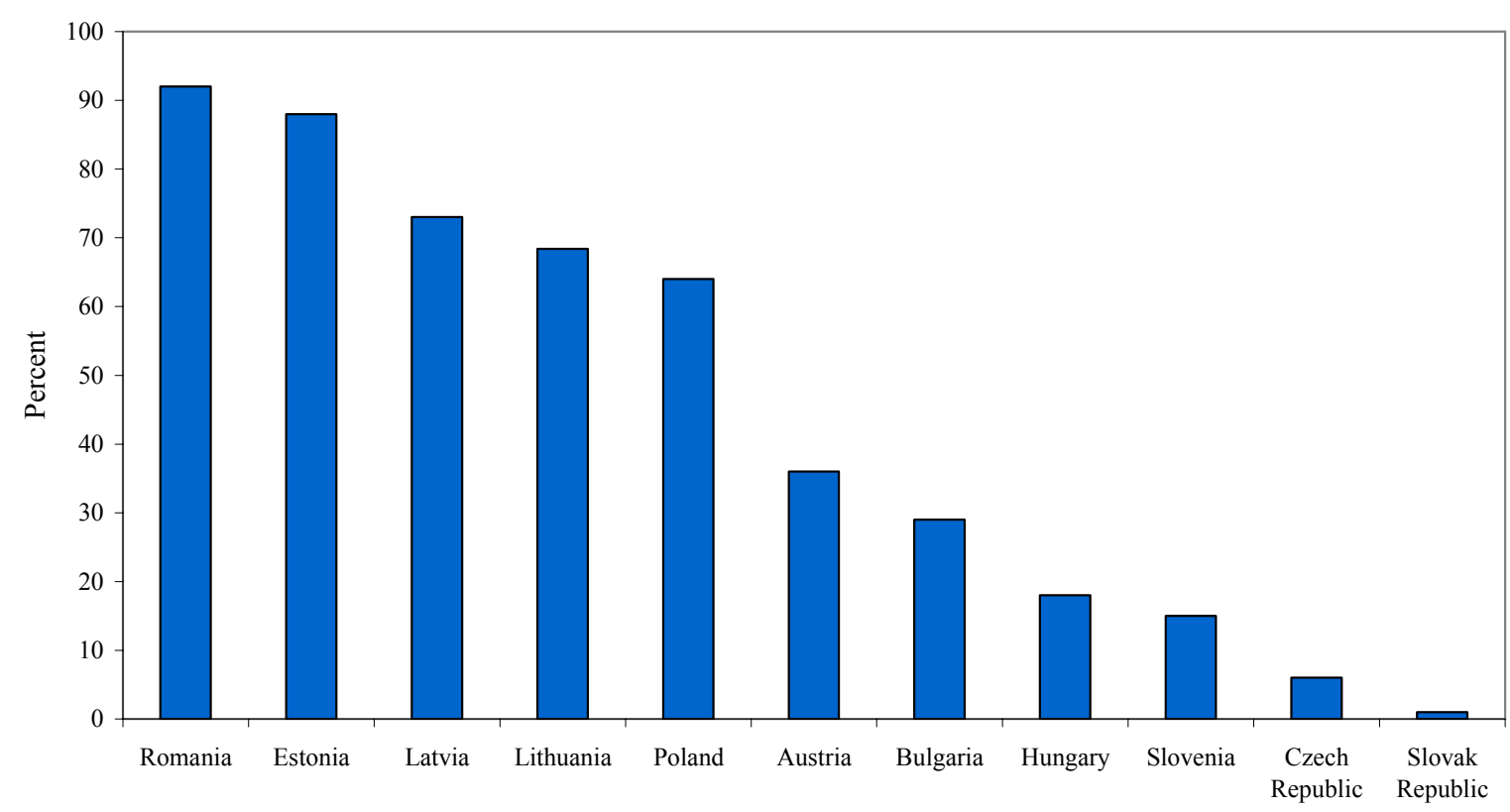

Source: National Bank of Poland, Bank of Lithuania.

\section{This chapter explores the above two questions using a gamut of methodologies}

and data. It examines aggregate and bank-level data for Poland and key comparator countries, undertaking new analyses and drawing on existing studies. It draws on discussions with policymakers and market representatives in Poland during the Financial Sector Assessment Program (FSAP) Update, as well as the analysis of credit issues in the Financial Stability Reports, Reports on Developments in the Financial System, and Summary Evaluations of the Financial Situation of Polish Banks prepared by the National Bank of Poland (NBP).

3. The chapter is organized as follows: Section II.B discusses credit developments in the last decade and factors driving these developments and assesses implications for economic growth. Section II.C examines reasons for rapid growth of foreign currency lending and implications for financial stability. Section II.D (and Appendix) review crosscountry experiences with policy responses to rapid credit growth of foreign currency credit and discuss recent policy measures taken in Poland. Section II.E concludes the chapter. 


\section{Why Has Credit Growth Been So Slow?}

\section{A. Analysis Based on Aggregate Data}

4. Overall credit growth in Poland has been slow since the early 2000s largely due to declining corporate credit, while household credit has been expanding briskly (Figures 1-2). Corporate credit growth, which had been falling since the late 1990s, bottomed out in early 2005, and since then has been slow to recover. These trends largely reflect slow growth of credit to private companies, which added to the negative contribution from declining credit to state-owned companies. Although also on a declining trend until recently, household credit growth has remained positive, and last year it overtook corporate credit as a share of total outstanding credit to the private sector. Housing loans have been among the fastest growing components of credit both in the household sector in recent years. Although credit card borrowing has also been growing rapidly, it still accounts for a very small share of total household credit.

\section{Lackluster credit growth during 2000-05 partly reflected weak economic} activity (Figures 3-4). As economic growth slowed in the early 2000s, corporate credit growth also started to slow from the double-digit rates of the 1990s. Despite a pickup in economic activity in 2003-04, corporate credit growth remained subdued. The main reason for slow corporate credit growth during this period was high corporate liquidity, which, against the backdrop of weak corporate investment, enabled companies to fund themselves internally. Corporate credit growth does not seem to have been crowded out by bond issuance or external borrowing, which remained subdued in recent years. Household credit growth also slowed in the early part of this decade, albeit less so than corporate credit growth. The slowdown in household credit largely reflected slower growth in loans for purchases of consumer durables, while housing credit continued to expand at a robust pace.

6. Supply-side factors also weighed on credit growth (Figures 3-4). As the economic environment deteriorated and loan defaults rose, banks, which had just started restructuring, became more cautious about extending new loans. The share of nonperforming loans (NPLs) in total corporate loans more than doubled in five years: from 13 percent in 1998 to almost 30 percent in $2003 .{ }^{2}$ According to the NBP, the quality of corporate loans in the distribution and construction sectors, which accounted for a substantial portion of banks' portfolios, deteriorated most significantly. Households' repayment capacity also weakened as unemployment rose and wage growth slowed, and the share of nonperforming loans in total household loans increased. In addition to slowing economic growth, overly lenient lending

\footnotetext{
${ }^{2}$ Strict loan classification rules and efforts of recently privatized banks to clean up their balance sheets contributed to the large increase in NPLs during this period.
} 
practices in the preceding years of credit expansion contributed to the significant deterioration in asset quality in the early part of this decade. ${ }^{3}$

Figure 1. Poland: Growth of Credit to the Private Sector, 1998-2006

(Annual percent change)
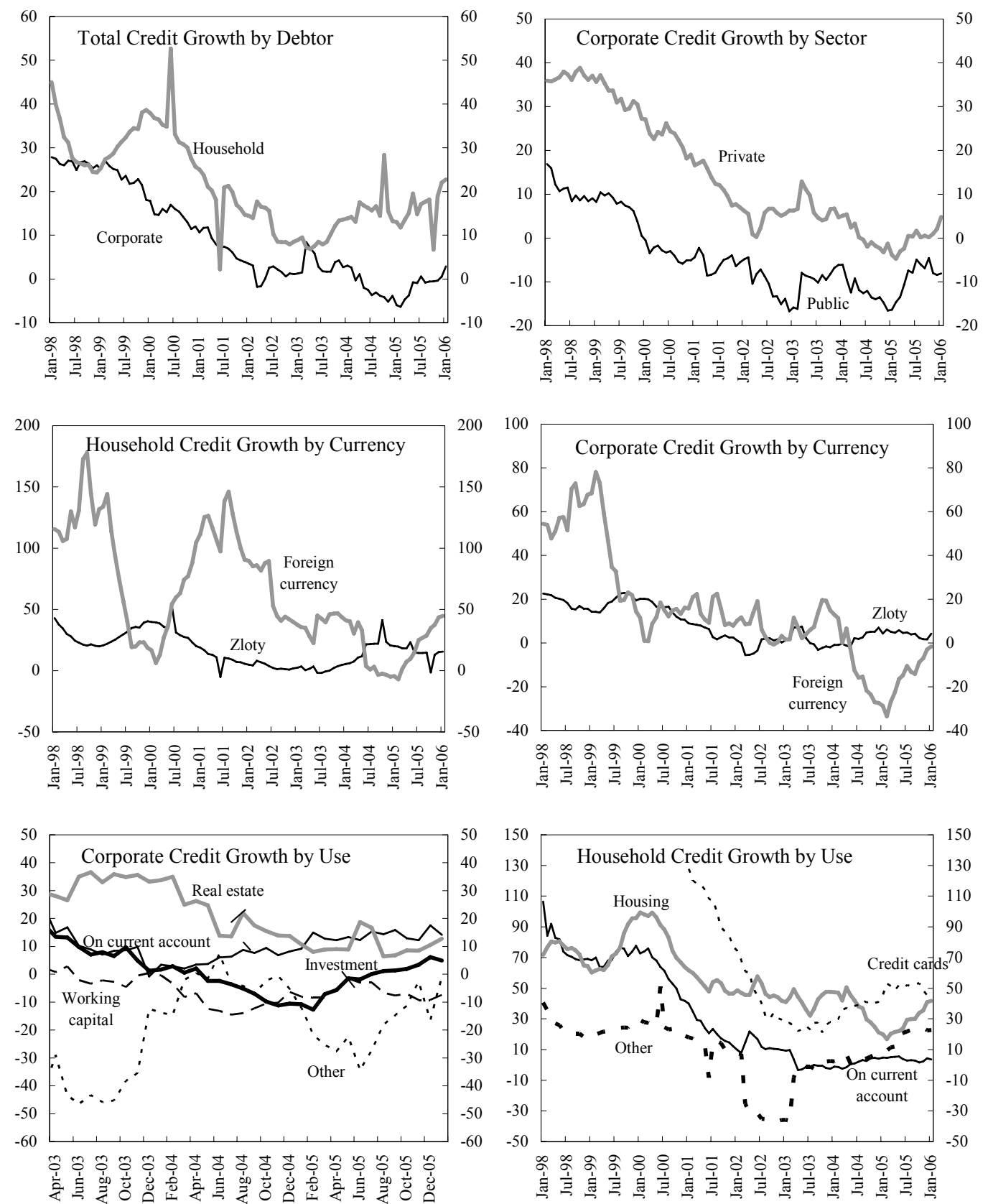

Source: National Bank of Poland.

${ }^{3}$ See the NBP's Summary Evaluation of the Financial Situation of Polish Banks, various issues. 
Figure 2. Poland: Composition of Credit to the Private Sector, 1996-2006 (In percent of total)
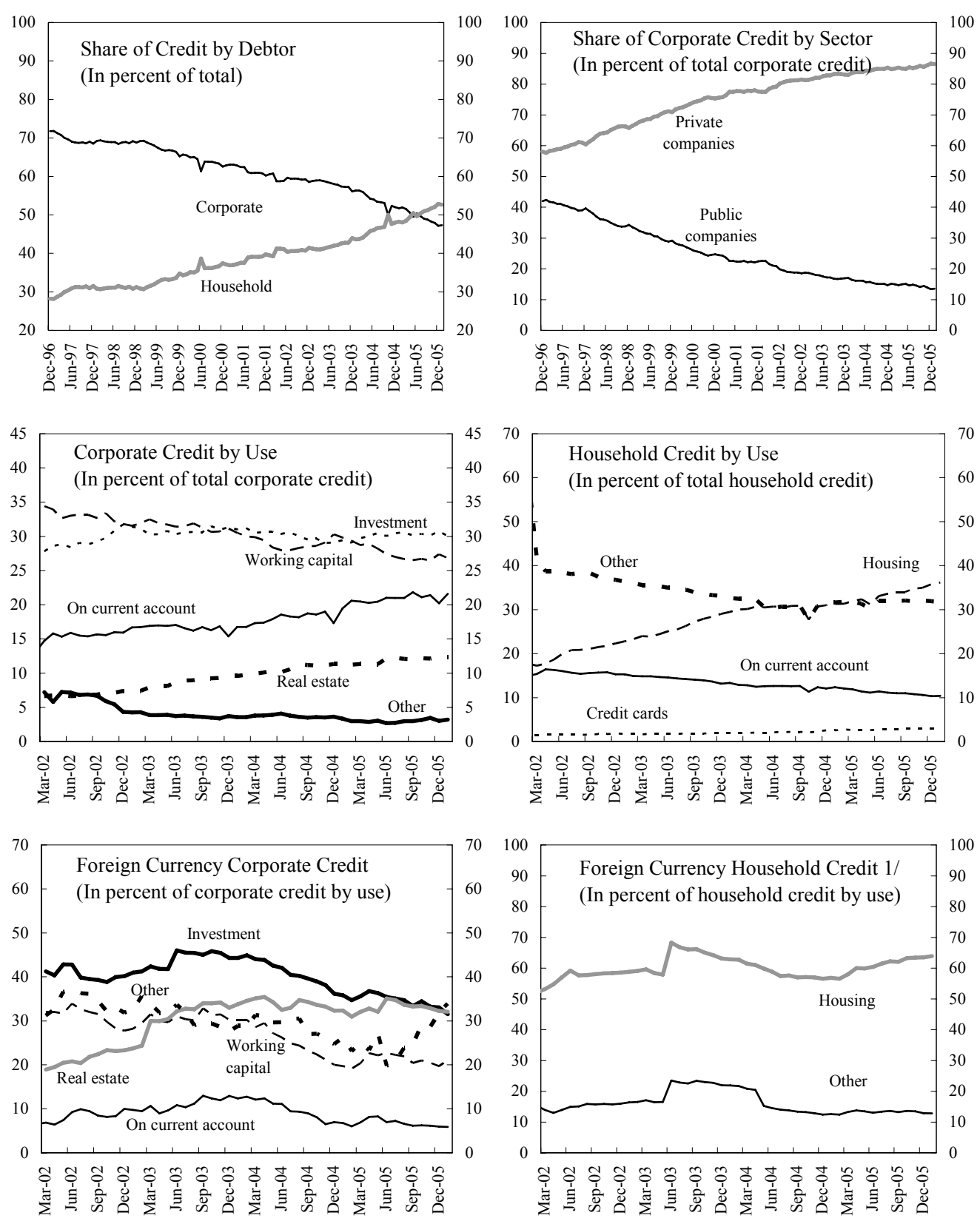

Source: National Bank of Poland.

1 / The shares of foreign currency-denominated loans in total credit card loans and in current account loans were below 2 percent during 2002-05 and are not reported. 


\section{An econometric analysis allows the demand- and supply-side factors of credit} growth to be explored in more detail. The analysis is based on a simple model, where the growth of aggregate bank credit to households and corporates depends on the basic proxies of loan demand (industrial production growth, wage growth, and unemployment) and loan supply (bank soundness), and real interest rates. ${ }^{4}$ Bank soundness is measured by the share of nonperforming loans in total outstanding loans, and distance to default (Box 1) is used for a robustness check. The model is estimated using the ordinary least squares on a sample from January 1998 to December 2005. Parsimonious specifications of the model are obtained using general-to-specific modeling, starting with 12 lags for all explanatory variables and sequentially eliminating statistically insignificant variables, while ensuring that reduced specifications encompass preceding specifications.

\section{Both demand- and supply-side variables are found to be significant}

determinants of credit growth in Poland (Table 1). Overall, demand-side factors seem to have been more important than supply-side factors in driving credit growth in Poland. The signs of coefficients in the long-run static solution of the model are generally in line with expectations. Higher household credit growth is found to be associated with higher industrial production, lower real interest rates, and stronger bank balance sheets. The unemployment rate and real wage growth seem to be less significant determinants of household credit growth than the above variables. In the model of corporate credit growth, lower wages, unemployment and real interest rates and stronger bank balance sheets are found to stimulate credit growth. Corporate credit growth is negatively correlated with industrial production growth, possibly reflecting the fact that strong retained earnings in recent years have enabled corporates to finance themselves internally.

\section{The econometric results confirm the procyclicality of both the demand and} supply of credit in Poland. During 1998-2005, loan demand seems to have declined as the economic activity slowed down. Bank loan supply also declined, as loan defaults weakened banks' balance sheets and reduced banks' willingness to lend. The finding that supply-side factors contributed to a slowdown in private sector loan growth is generally robust using distance to default as a measure of bank soundness. It is also consistent with recent literature, which shows how weaknesses in bank balance sheets can reduce bank loan supply not only in crisis but in normal times as well (Dell'Ariccia, Detragiache, and Rajan, 2005; and Nier and Zicchino, 2006).

\footnotetext{
${ }^{4}$ Including other macroeconomic variables does not significantly improve the specification.
} 


\section{Box 1. Distance to Default as a Summary Measure of Bank Soundness}

Distance to default (DD) has become an increasingly popular measure of bank soundness (see, for example, Danmarks Nationalbank, 2004; and De Nicoló and others, 2005). Its popularity stems from the fact that it is directly related to the probability of default - that is the probability that the value of assets becomes smaller than the value of debt. It can be summarized as $\mathrm{DD} \equiv(\mathrm{k}+\mu) / \sigma$, where $\mathrm{k}$ is equity capital as percent of assets, $\mu$ is average return as percent on assets, and $\sigma$ is the standard deviation of return on assets as a proxy for return volatility. DD measures the number of standard deviations a return realization has to fall in order to deplete equity, under the assumption of normality of banks' returns. Because a higher DD corresponds to a lower upper bound of insolvency risk, a higher DD therefore implies a lower probability of insolvency risk.

Typically, market values of equity are used to calculate this index (see, for example, De Nicoló and others, 2005). In particular, daily market data on equity are combined with annual accounting data to calculate the market value and the volatility of assets, based on the optionpricing model by Black and Scholes (1973) and Merton (1974). Advantages of using stock market data include the fact that they aggregate information dispersed among market agents and potentially can provide forward-looking assessments of risks. However, this approach is also based on relatively strong assumptions; in particular, it requires bank stocks to be traded in well-functioning and liquid markets.

Since this assumption might not hold in relatively illiquid NMS stock markets, this paper mainly uses a simpler annual measure of DD based only on balance sheet and income statement data (also known as z-score; for example, Maechler, Mitra, and Worrell, 2006). DD is calculated using annual data on equity capital and return on assets. The standard deviation of returns is calculated for the entire sample period to obtain a sufficiently longterm view on the risks faced by a given bank. DD measure should be robust to changes in loan classification rules introduced in Poland in 2004. Only in the econometric analysis based on monthly aggregate credit data (Section II.A), the paper uses DD measure calculated by combining accounting data with stock market data (in the way suggested by De Nicoló and others, 2005). 
Figure 3. Poland: Private Sector Credit and Macroeconomic Environment, 1997-2005 1/

(Annual percent change, unless indicated otherwise)
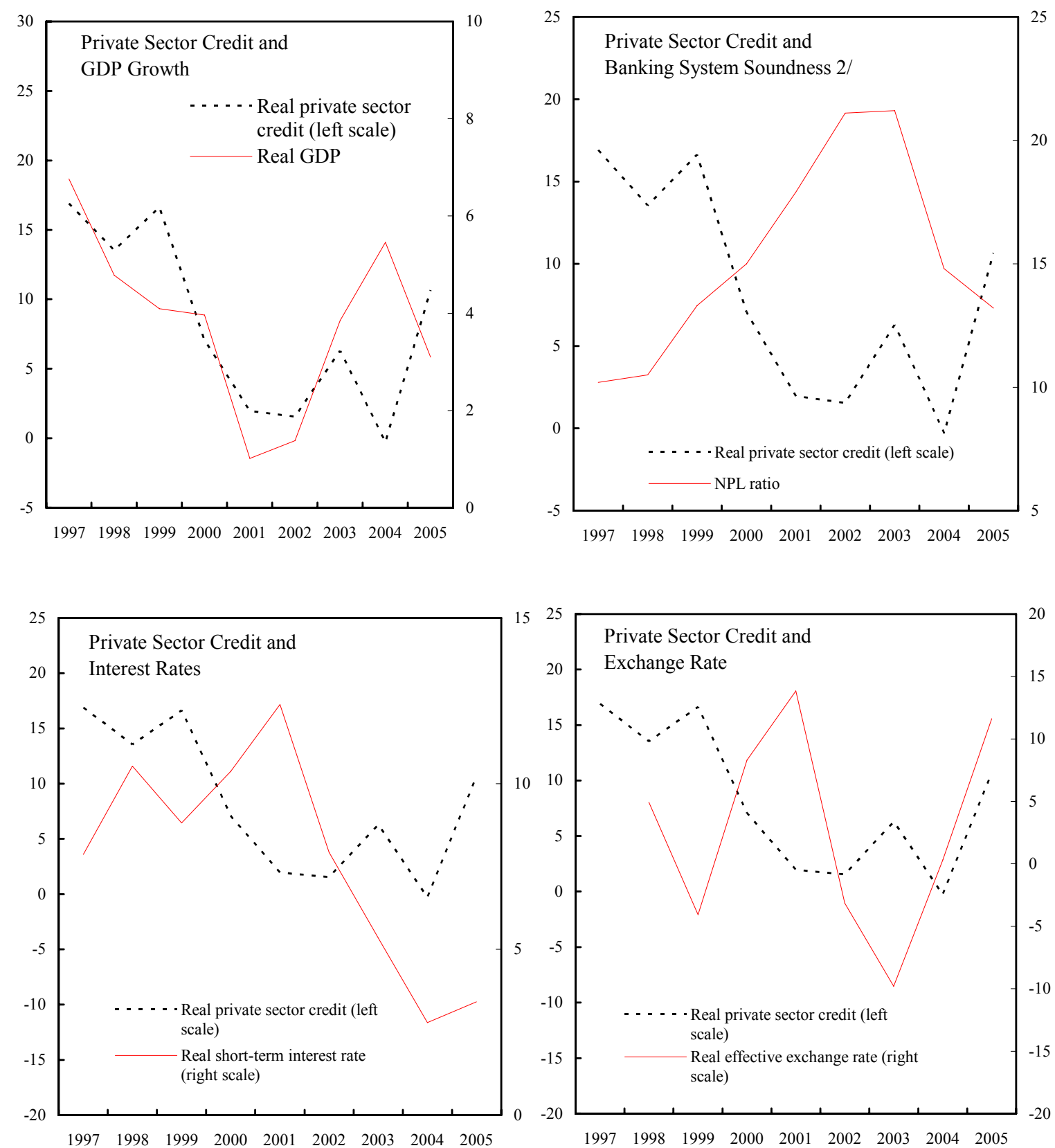

Sources: National Bank of Poland; Polish Statistical Office; and IMF staff estimates.

1/ LHS indicates left-hand scale, and RHS indicates right-hand scale.

2/ NPL ratio is the share of nonperforming loans in total loans. 
Figure 4. Poland: Demand and Supply Factors Driving Private Sector Credit, 1997-2005 1/

(Annual percent change, unless indicated otherwise)
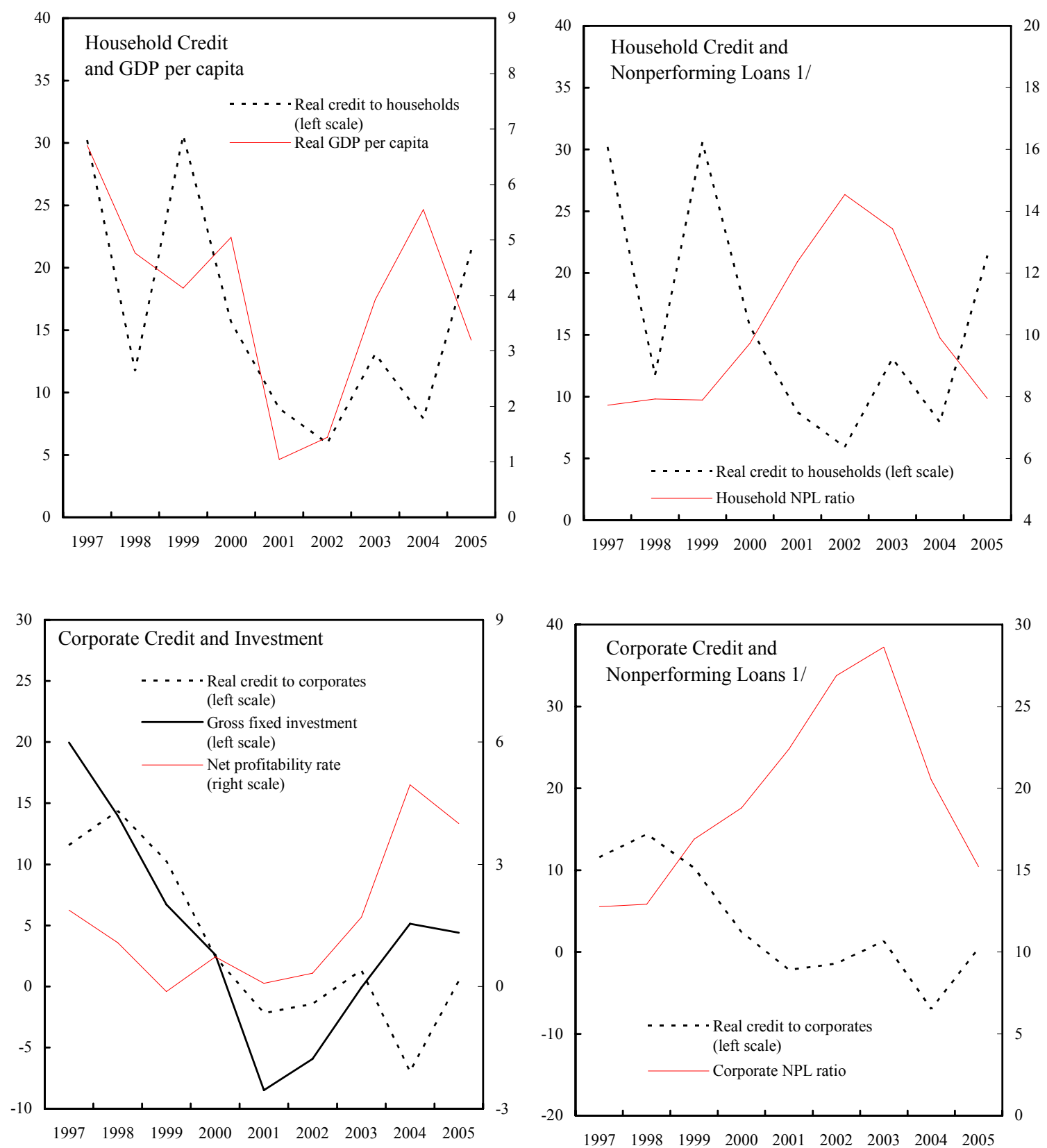

Sources: National Bank of Poland; Polish Statistical Office; and IMF staff estimates.

$1 /$ NPL ratio is the ratio of nonperforming loans to total loans. 
Table 1. Poland: Modeling Growth of Credit to the Private Sector

\begin{tabular}{|c|c|c|c|c|c|}
\hline \multicolumn{3}{|c|}{ Household Credit Growth } & \multicolumn{3}{|c|}{ Corporate Credit Growth } \\
\hline & Coefficient & Probability & & Coefficient & Probability \\
\hline Constant & 0.054 & 0.000 & Constant & 0.032 & 0.000 \\
\hline Dtlhr_1 & -0.304 & 0.002 & Dtlcr_3 & -0.205 & 0.008 \\
\hline Dtlhr_2 & -0.193 & 0.041 & Dtlcr_12 & 0.489 & 0.000 \\
\hline Dtlhr_7 & -0.105 & 0.271 & Dip_2 & -0.103 & 0.017 \\
\hline Dtlhr_11 & -0.140 & 0.116 & Dip_3 & -0.105 & 0.010 \\
\hline Dip_6 & 0.438 & 0.000 & Dip_8 & -0.088 & 0.031 \\
\hline Dip_7 & 0.472 & 0.000 & Dip_12 & -0.113 & 0.003 \\
\hline Dip_8 & 0.181 & 0.078 & Dwr_7 & -0.186 & 0.004 \\
\hline Dwr_7 & -0.236 & 0.088 & Dwr_11 & -0.267 & 0.000 \\
\hline DRUP_6 & 0.016 & 0.130 & DRUP_2 & -0.028 & 0.000 \\
\hline DRUP_9 & 0.009 & 0.416 & DRPR_4 & -0.005 & 0.003 \\
\hline DRPR_4 & -0.009 & 0.006 & DRPR_7 & -0.004 & 0.003 \\
\hline DRPR_10 & -0.008 & 0.010 & DRPR_9 & 0.003 & 0.024 \\
\hline NPLRT_6 & 0.015 & 0.016 & NPLRT_11 & -0.002 & 0.000 \\
\hline NPLRT_7 & -0.046 & 0.000 & & & \\
\hline NPLRT_8 & 0.033 & 0.001 & & & \\
\hline NPLRT_11 & -0.018 & 0.020 & & & \\
\hline NPLRT_12 & 0.014 & 0.027 & & & \\
\hline \multirow{2}{*}{\multicolumn{2}{|c|}{$\begin{array}{l}\text { Adjusted R-squared } \\
\text { Observations }\end{array}$}} & 0.43 & \multicolumn{2}{|l|}{ Adjusted R-squared } & 0.58 \\
\hline & & 96 & \multicolumn{2}{|l|}{ Observations } & 96 \\
\hline \multicolumn{6}{|c|}{$\underline{\text { Specification Tests }}$} \\
\hline & Statistic & \multicolumn{2}{|l|}{ Probability } & Statistic & Probability \\
\hline Chow test & 1.328 & 0.239 & Chow test & 0.564 & 0.822 \\
\hline Autocorrelation test 1 & 0.860 & 0.492 & Autocorrelation test 1 & 0.331 & 0.857 \\
\hline Autocorrelation test 2 & 0.846 & 0.501 & Autocorrelation test 2 & 0.985 & 0.421 \\
\hline \multirow[t]{3}{*}{ Heteroskedasticity test } & 0.828 & 0.713 & Heteroskedasticity test & 0.867 & 0.647 \\
\hline & & \multicolumn{3}{|c|}{ Long-Run Static Solution 2/ } & \\
\hline & Statistic & Probability & & Statistic & Probability \\
\hline Dip & 0.626 & 0.000 & Dip & -0.572 & 0.000 \\
\hline Dwr & -0.135 & 0.097 & Dwr & -0.632 & 0.000 \\
\hline DRUP & 0.014 & 0.093 & DRUP & -0.039 & 0.000 \\
\hline DRPR & -0.010 & 0.001 & DRPR & -0.009 & 0.015 \\
\hline NPLRT & -0.001 & 0.000 & NPLRT & -0.002 & 0.000 \\
\hline Constant & 0.031 & 0.000 & Constant & 0.045 & 0.000 \\
\hline
\end{tabular}

Source: IMF staff estimates.

Notes: The dependent variable is the monthly percent change in real credit to households (Dtlhr) or nonfinancial corporations (Dtlcr). Explanatory variables, all seasonally adjusted, include the monthly percent change in industrial production (Dip) and real average gross wages (Dwr), and the month-on-month change in the unemployment rate (DRUP) and the real policy rate (DRPR), and nonperforming loans as a share of total household or corporate loans (NPLRT). "D" denotes a one-period difference, and lower case letters indicate logarithms. The model was estimated using the ordinary least squares on a sample from January 1998 to December 2005. Parsimonious dynamic models were obtained using general-to-specific modeling, starting with 12 lags for all explanatory variables. The long-run solution corresponds to the following equation: Dtlhr or Dtlcr $=\beta 1+\beta 2 *$ Dip $+\beta 3 *$ Dwr $+\beta 4 *$ DRUP $+\beta 5 *$ DRPR $+\beta 6 *$ DNPRT. 


\section{B. Analysis Based on Bank-Level Data}

10. This section explores the reasons for slow credit growth in Poland by drawing on a cross-country study on credit growth and bank soundness in the NMS. ${ }^{5}$ Using bank-level data, the study identifies the key factors driving credit growth in the region during the last decade and assesses its prudential implications. The econometric analysis is based on a simultaneous equation framework, which takes into account feedback between credit growth and financial stability and enables a joint estimation of their determinants.

\section{The econometric analysis suggests that Poland's credit growth has been} "underperforming" in recent years by the NMS's standards. In the second half of the 1990s credit growth in Poland was consistent with the country's level of income, cyclical position, and banking sector characteristics (the coefficient on the dummy variable identifying Polish banks is statistically insignificant in Table 2, Column 3). In contrast, during 2001-04, credit growth was $14 \frac{2}{3}$ percentage points per year lower on average than would be expected, given the structural determinants of credit growth (the coefficient on the Polish bank dummy is negative and statistically significant in Table 2, Column 7). ${ }^{6}$

\section{In recent years, the structural determinants of credit growth included real} GDP growth, profitability (approximated by the net interest margin), and real exchange rate changes. The importance of the level of economic and institutional development, bank efficiency (measured by the cost-to-income ratio), and real interest rates weakened in 2001-04 compared to 1994-2000. During 2001-04, bank soundness seems to have had a positive and statistically significant impact on credit growth in Poland, in contrast to the insignificant impact found in other NMS (Table 2, Column 4). The deterioration in bank balance sheets triggered by the 2001-02 economic slowdown seems to have had a larger impact on credit growth in Poland than in other NMS, possibly because it coincided with the start of restructuring by new foreign owners of several key banks or because it came on the heels of rapid credit expansion in the early 1990s in an environment of weak lending practices. $^{7}$

\footnotetext{
${ }^{5}$ See the Technical Note on "Credit, Growth, and Financial Stability."

${ }^{6}$ Data for an outlier - a rapidly growing but reportedly weak small domestically owned Polish bank-were excluded from the data set. Regular loans accounted for about half of this bank's loan portfolio, possibly because, for tax reasons, it has been slow to write off these loans.
}

${ }^{7}$ NBP, Summary Evaluation of the Financial Situation of Polish Banks, various issues. 
Table 2. Credit Growth in Poland Compared to Other New Member States, 1995-2004 1/

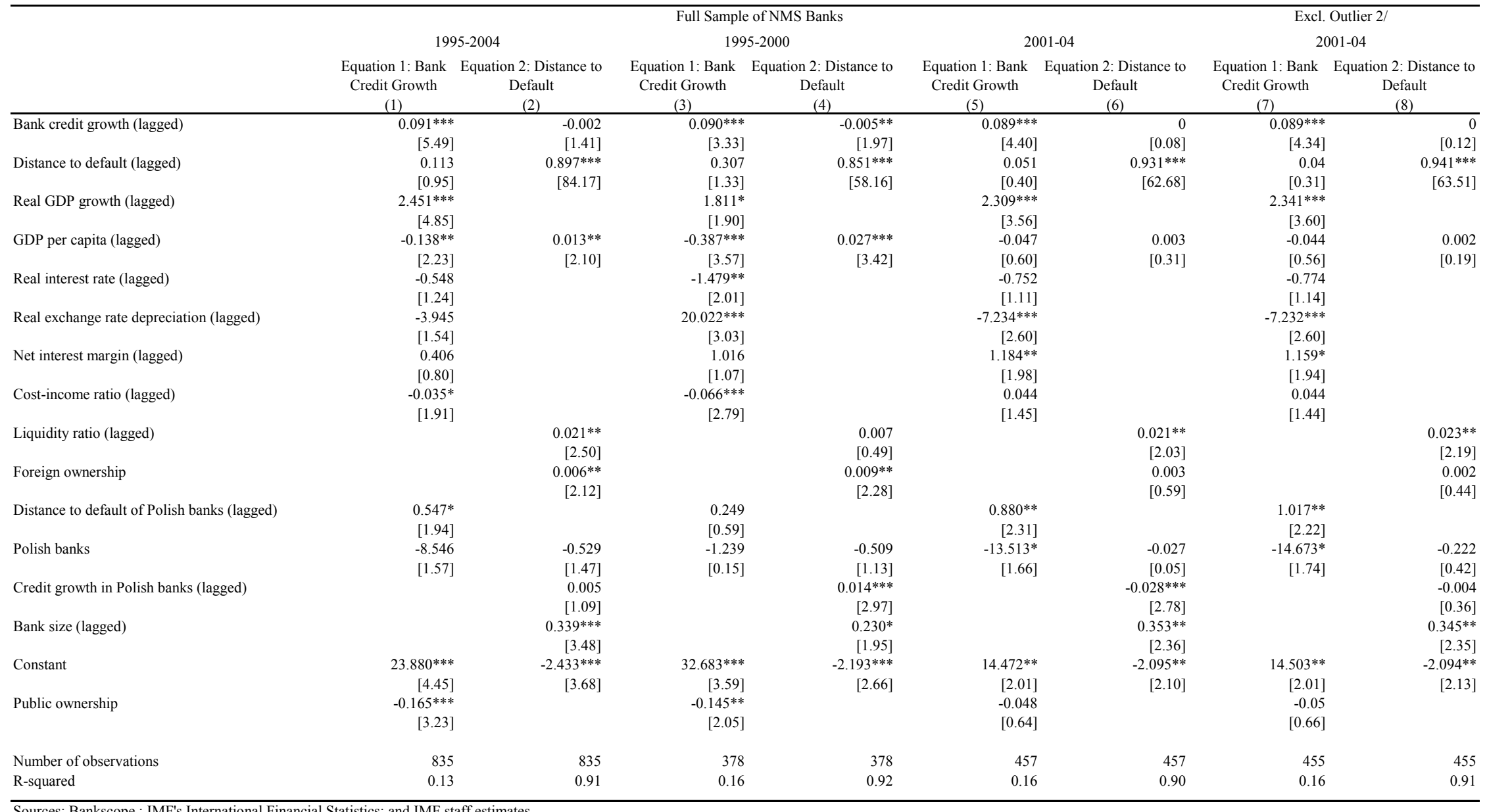

Sources: Bankscope, IMF's International Financial Statistics; and IMF staff estimates.

$1 /$ The absolute value of $\mathrm{z}$ statistics is in brackets. An asterisk * $(* *, * *)$ indicates significance at the 10 percent ( 5 percent, 1 percent) level. The sample covers commercial banks from the new EU member states for which data are available in Bankscope. The dependent variable in the first equation is the annual percent change in outstanding bank loans, deflated using the CPI index. In the second equation, the dependent variable is distance to default (DD), calculated using bank account data. Exogenous variables include annual real GDP growth, GDP per capita in U.S. dollars, real lending interest rates, annual percent change in the real exchange rate of local currency vis-a-vis the U.S. dollar, net interest margin, costto-income ratio, liquidity ratio, and bank size (measured by total assets in U.S. dollars), all lagged by one year. The model also includes the shares of bank capital held by foreign institutions and by the government, a dummy variable for Polish banks, and two interaction terms (the annual percentage change in outstanding bank loans multiplied by the dummy for Polish banks and DD multiplied by the dummy for Polish banks). The model is estimated using three-stage least squares.

2/ Excluding data for one small rapidly growing Polish bank with a large share of irregular loans.

\section{CInternational Monetary Fund. Not for Redistribution}




\section{One possible reason for slow credit growth in Poland in recent years relates to} weaknesses in the enforcement of pledges and collateral. According to the European Bank for Reconstruction and Development, Poland scores the worst among NMS on the process aspects relating to the enforcement of pledges and collateral: (i) time, amount, and simplicity of enforcement; (ii) debtor obstruction, that is, the possibility for the debtor to obstruct the enforcement proceedings to the detriment of the chargeholder; (iii) creditor control, that is, the ability of the creditor to control or influence the conduct of the enforcement procedure; and (iv) institutions, that is, the reliability of courts and other institutions necessary to support the enforcement process. ${ }^{8}$ Weaknesses in the enforcement of pledges and collateral are likely to weigh on banks' willingness to lend, reducing loan growth and the pace of financial deepening. In addition, reported difficulties in collecting accurate information about prospective corporate borrowers, especially small and medium-size enterprises, might have discouraged credit growth in Poland. ${ }^{9}$

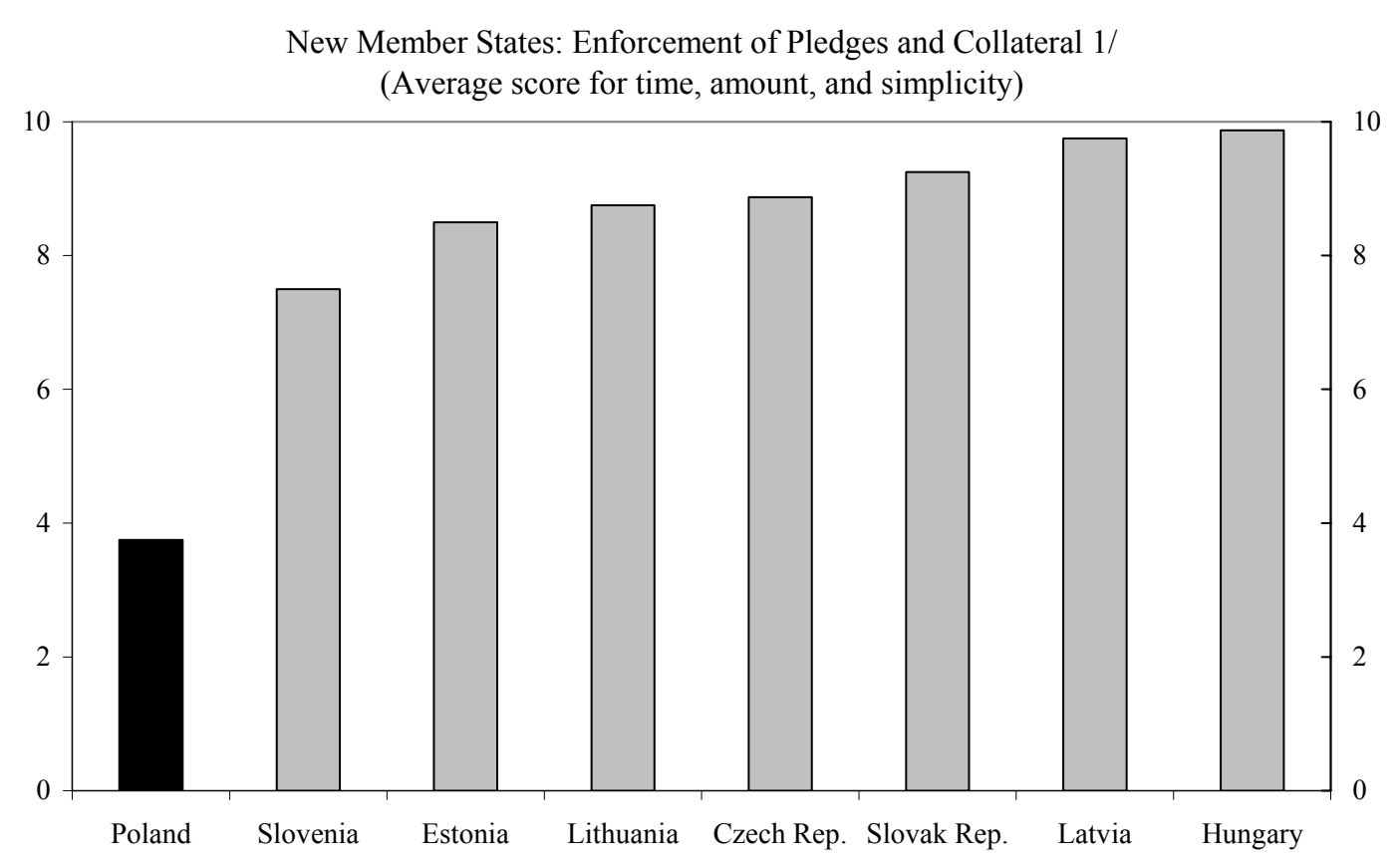

Source: European Bank for Reconstruction and Development.

$1 /$ Ratings for each dimension range from 0 (worst) to 10 (best).

\footnotetext{
${ }^{8}$ EBRD (2005). See also World Bank (2006).

${ }^{9}$ Although progress has been made recently in addressing these obstacles to the provision of private sector credit, there is still considerable room for improvement.
} 


\section{Unless the institutional impediments to credit growth are addressed, Poland} risks falling behind not only in financial development but also in broader economic performance. To the extent that slow credit growth in Poland reflected cyclical factors, it can be expected to pick up as the economy recovers. Indeed, recent loan statistics and senior loans officers' surveys point to strengthening demand for corporate and household credit. However, if, even during an economic upturn, credit growth remained below the level consistent with structural determinants, this would raise concerns about the implications for long-run economic growth. Recent literature suggests that financial development is crucial for fostering economic growth (King and Levine, 1993; and Rajan and Zingales, 1998). Such growth-enhancing benefits are likely to be particularly relevant for countries like Poland, where credit markets seem to be underdeveloped relative to other economies with similar levels of income, reflecting the legacy of central planning (Coricelli and Masten, 2005).

\section{Is RAPID GROWTH OF ForeIgn CURRENCY HOUSING LENDING A CONCERN FOR FINANCIAL STABILITY?}

\section{A. Background}

\section{Against the backdrop of slow overall credit growth, housing loans were the} fastest growing component of private sector credit in the last decade. During the last four years, housing loans grew at an average rate of 40 percent per year. High demand for flats and houses in an environment of falling interest rates fueled housing credit, even as the growth of employment and disposable income was sluggish. One-off effects of EU accession also contributed, particularly an announcement about forthcoming VAT hikes for construction materials and expectations of rising property prices in the wake of EU accession. As new banks entered the market and bank competition intensified, banks started to offer special promotions on household loans, which also helped stimulate demand.

16. Foreign currency loans dominate lending for housing purposes. While the share of foreign currency-denominated or indexed loans in total loans in Poland is not high by regional comparison (25 percent at end-2005) and has been declining in recent years, about 64 percent of housing loans were indexed to or denominated in foreign currency at end2005 - significantly more than in other NMS and one of the highest percentages in the EU. Borrowing in foreign currency for housing purposes has been attractive for households, given the still significant interest rate differential between zloty and foreign currency-indexed loans, widely held expectations of continued zloty appreciation, and the long-term maturity of housing loans (up to 30 years). ${ }^{10}$ Most housing loans are at variable interest rates.

\footnotetext{
${ }^{10}$ In recent years, the Swiss franc has become a currency of choice for housing loans, because Swiss franc loans carry the lowest interest rate among foreign currency loans. Typical mortgage loan amounts are still relatively low, roughly zloty $70,000-200,000$ (US\$25,000-75,000 or 2.0-5.5 times GDP per capita). Based on partial information, initial loan-to-value ratios (LTV) tend to be around 70 percent- 85 percent.
} 
Selected New Member States: Foreign Currency-Denominated and Indexed Loans to the Private Sector (In percent of total loans)

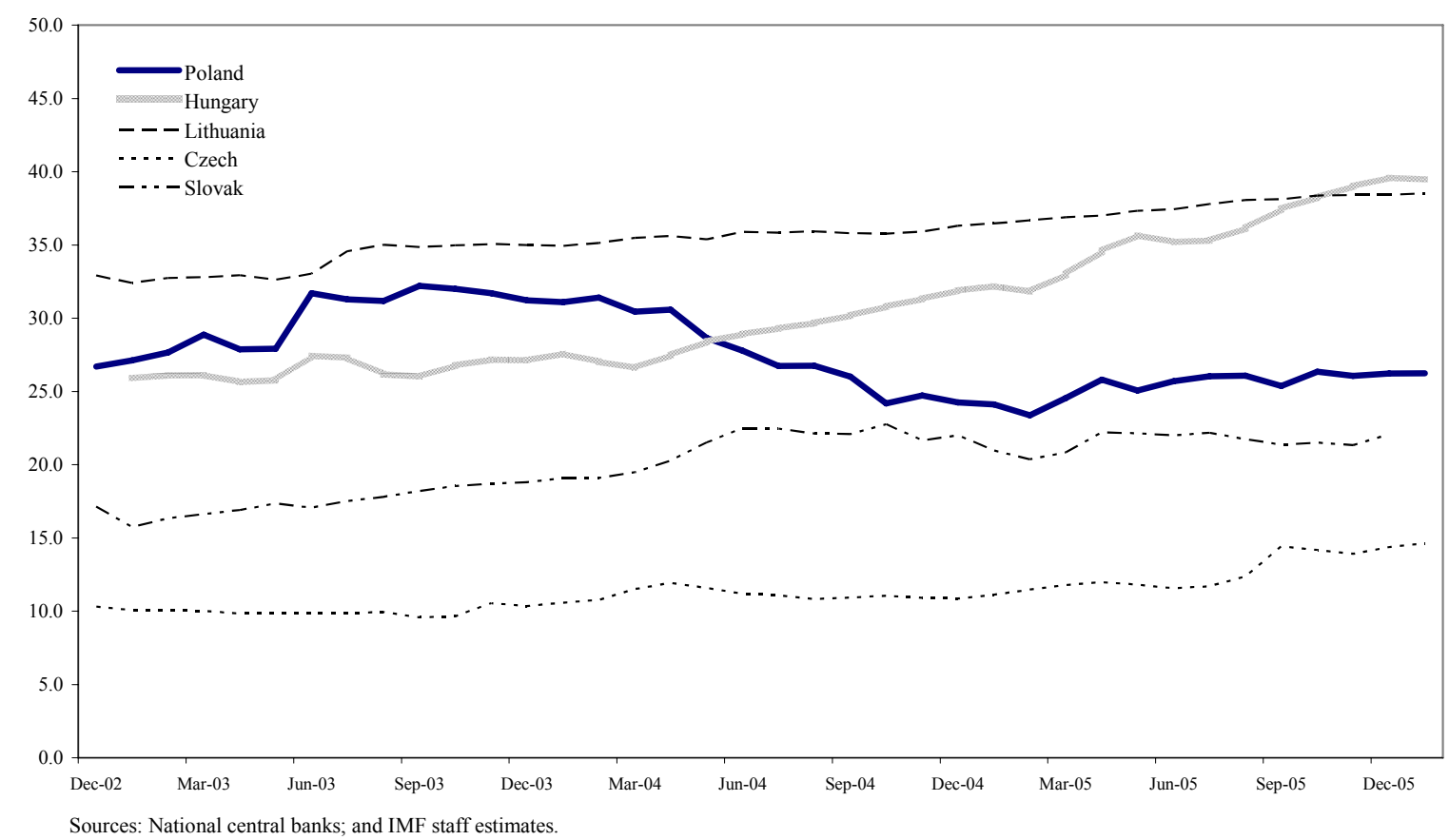

B. Analysis of Risks Associated with Foreign Currency Housing Lending

\section{Rapid growth of foreign currency housing loans raises concerns about banks'} exposure to indirect exchange rate risk. Households are typically unhedged, which makes them vulnerable, should the zloty significantly depreciate. ${ }^{11}$ The customer base for housing loans might also be changing: after several years of double-digit growth, foreign currency housing loans might be increasingly extended to individuals with lower income levels than in the past. A potential warning sign is a rising share of housing loans classified as satisfactory but repaid with a delay (up to 3 months), which supervisors are monitoring carefully. It is also possible that risk management practices in individual banks that are most aggressively engaged in foreign currency mortgage lending have weakened in a highly competitive environment. Another reason for concern is that in a country like Poland, with a short credit history, the institutional systems for the enforcement of collateral have been largely untested. The EBRD's recent assessment of these systems does not provide comfort that in the event of a large shock banks would be able to recover a significant portion of housing assets quickly (EBRD, 2005).

\footnotetext{
${ }^{11}$ However, borrowers using zloty-denominated loans would also be vulnerable, if a large depreciation is accompanied by a significant increase in interest rates.
} 
18. Yet, several considerations provide some comfort about the degree of exchange rate-related credit risks. First, market penetration is still low-outstanding mortgage loans accounted for about 6 percent of GDP in mid-2006, covering about 3 percent of the population. Borrowing in foreign currency for housing purposes is reportedly concentrated in the upper middle income group. Income eligibility requirements for foreign currency loans are typically higher than for zloty-denominated loans, resulting in a buffer of up to 20 percent depreciation. Asset quality indicators for foreign currency housing loans have so far been better than those for zloty-denominated loans and total household loans. Lastly, housing loan contracts typically allow individuals to change the currency denomination of loans freely during the loan period, which gives borrowers an opportunity to offload exchange rate risks if they expect the zloty to depreciate. (These provisions are unlikely to provide a "safety valve" in the event of a sharp unexpected depreciation.)

\section{Based on available data, the risk of a decline in housing prices does not appear} excessive. Data on nationwide real estate developments in Poland are sketchy. In particular, the time series of secondary market data are available only for the Warsaw agglomeration and only since 2002. Broader data are available only as snapshots for selected periods. Primary market data and other proxies (for example, rents) are available for longer time periods. ${ }^{12}$ Based on these partial data, it appears that housing prices have increased steadily since 2000, partly reflecting housing shortages against the backdrop of rising incomes. During 2003-05, the growth of housing prices slowed, but, as expected, it remained above consumer price inflation. Recent housing price growth in Poland was not excessive by comparison with Poland: Housing Prices, 2003-05 (Annual percent change) other EU countries.

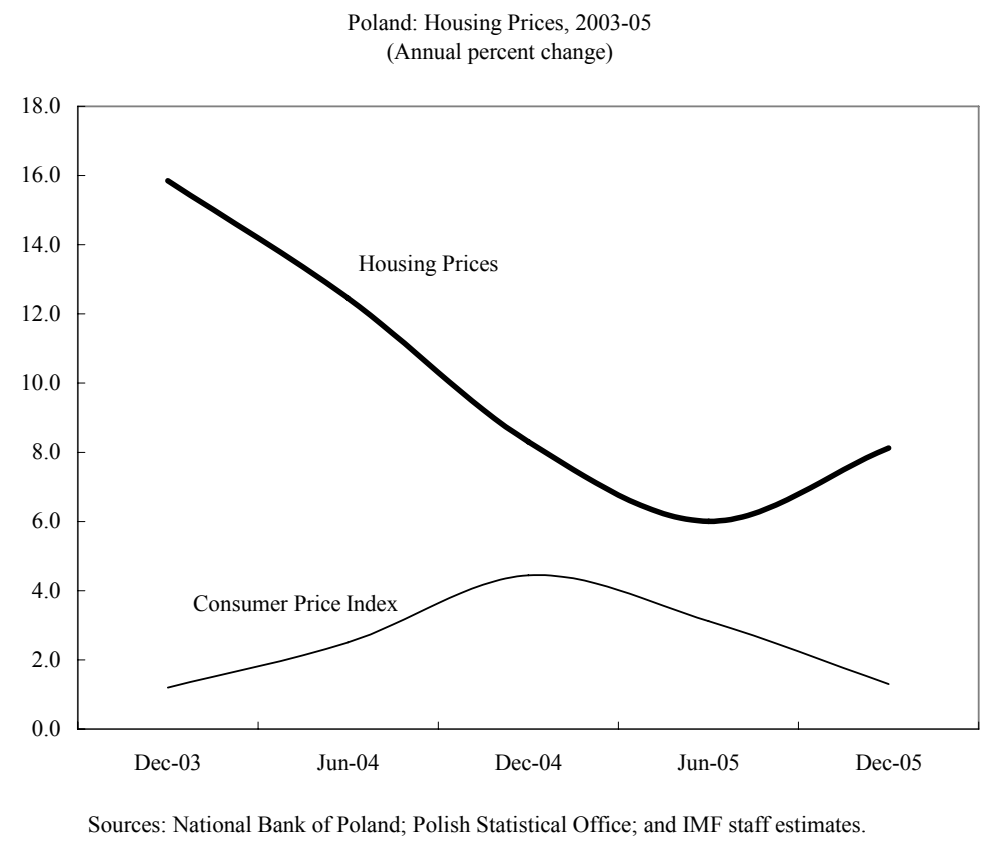

The annual growth rates of housing prices in 2004-05 in Poland were only marginally higher than the EU-15 average and below growth rates in France, Ireland, and Spain, for example. ${ }^{13}$

${ }^{12}$ Data limitations hindered stress testing for housing price risks in the FSAP Update. 
Selected European Countries: Housing Prices, 2004-05

(Annual percent change)

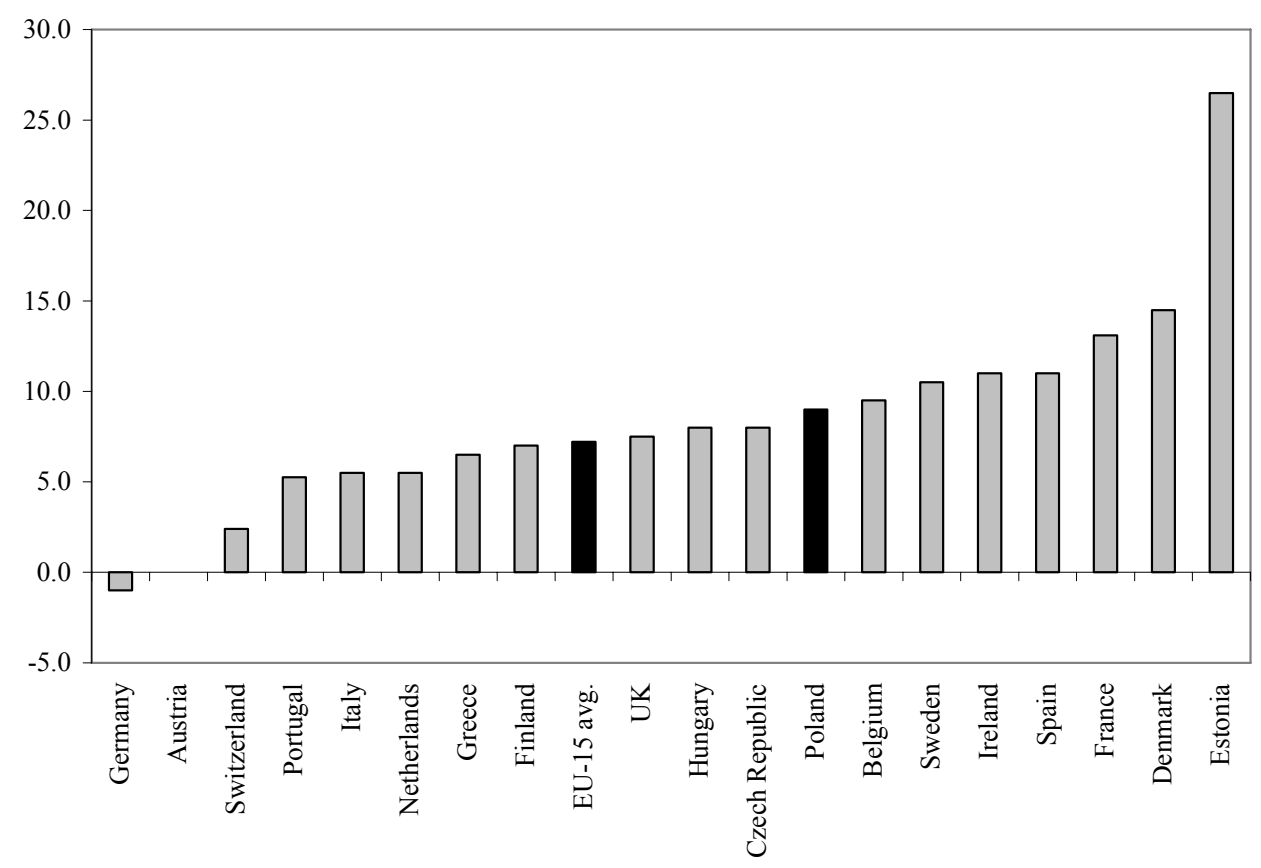

Sources: Royal Institute of Chartered Surveyors (United Kingdom); and IMF staff estimates.

\section{Liquidity risks also seem to be under control, although close monitoring of} foreign currency liquidity needs to continue. For the system as a whole, deposits taken from customers exceed loans granted to customers. At the level of individual banks, however, there are substantial differences, and most small banks have to rely on additional sources of funding than customer deposits. Liquid assets have been rising in proportion to total assets, and have recently exceeded liabilities toward the financial sector, the least stable funding source. An important part of total liquidity is foreign currency liquidity, with shortterm foreign currency claims constituting about one third of liquid assets. Foreign currency liquidity has been rising in recent years, as banks have increased short-term external borrowing in tandem with domestic foreign currency lending. According to the NBP, banks have so far been able to obtain foreign currency liquidity through transactions in the foreign exchange swap market without incurring excessive costs (NBP, 2005). Nonetheless, foreign currency liquidity should continue to be closely monitored, especially since banks tend to hedge the direct exchange rate risk from the rapidly growing foreign currency mortgages using short-term foreign currency swaps.

\footnotetext{
${ }^{13}$ Nonetheless, the collateral risk should not be discounted, given the identified problems with the enforcement of collateral rights (EBRD, 2005).
} 


\section{Next, this section examines how significant credit risks associated with housing} lending are and how resilient the banking system is to these risks in more detail, using a variety of analytical approaches and data. The section reviews aggregate indicators for the household sector, financial soundness indicators for Polish banks, and stress testing results. It also undertakes the econometric analyses of credit risk and bank soundness in the countryspecific and regional contexts.

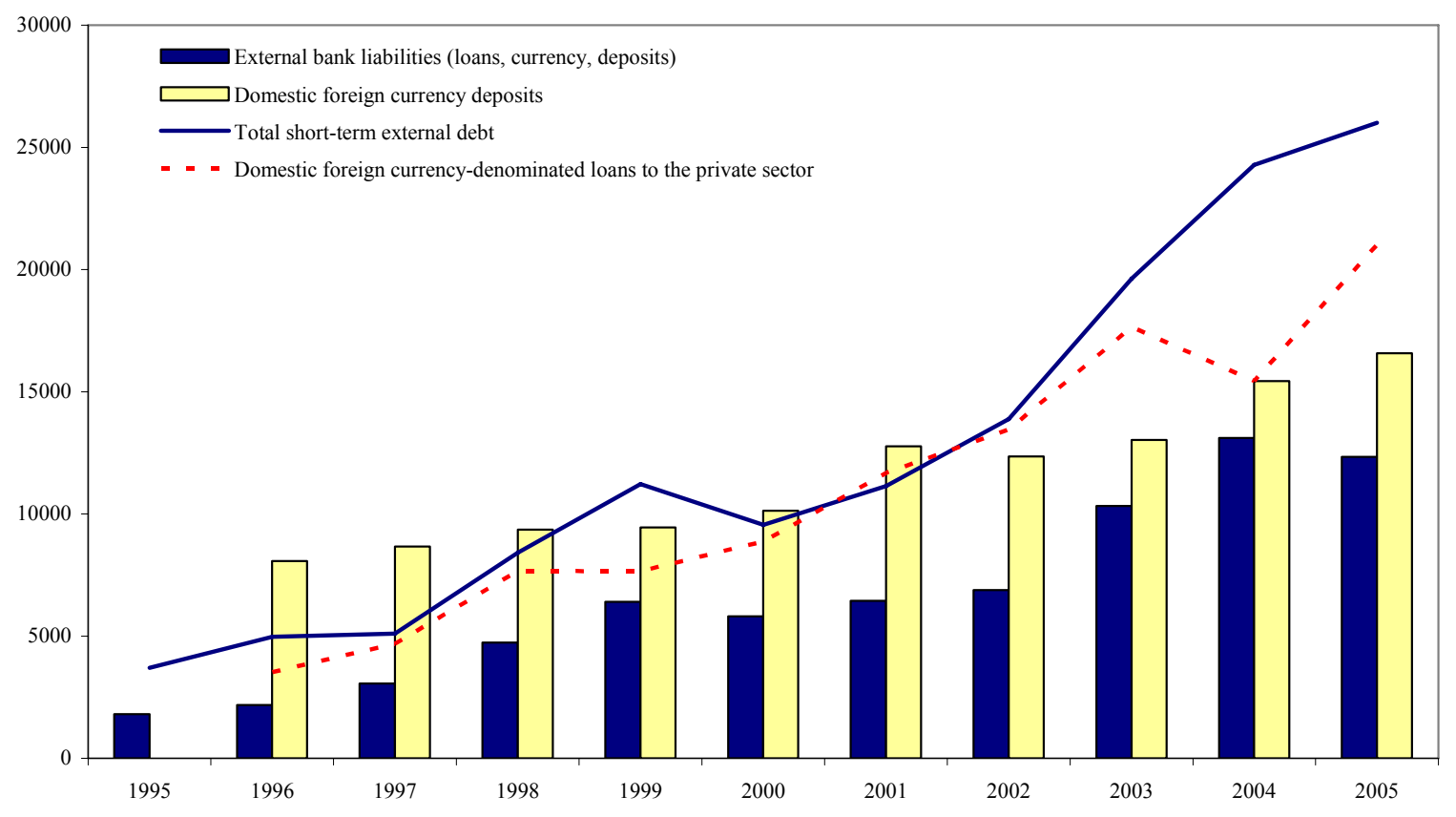

Sources: National Bank of Poland; Polish Statistical Office; and IMF staff estimates.

\section{The balance sheet of the household sector}

22. Aggregate household debt burden seems manageable. Household indebtedness has been gradually rising from a low base and, at about 15 percent of GDP in 2005, does not seem excessive by cross-country standards. In 2005, household borrowing corresponded to 21 percent of annual gross disposable income and 36 percent of households' financial assets. Households' debt service ratio was 16 percent of disposable income. However, these indicators refer to the household sector as a whole and, hence, should be taken with caution: they might mask pockets of vulnerabilities, for example, in low income groups of households or small- and medium-size enterprise. Disaggregated data on household balance sheets are, unfortunately, not readily available. 
Poland: Household Indebtedness, 2002-05

(In percent)

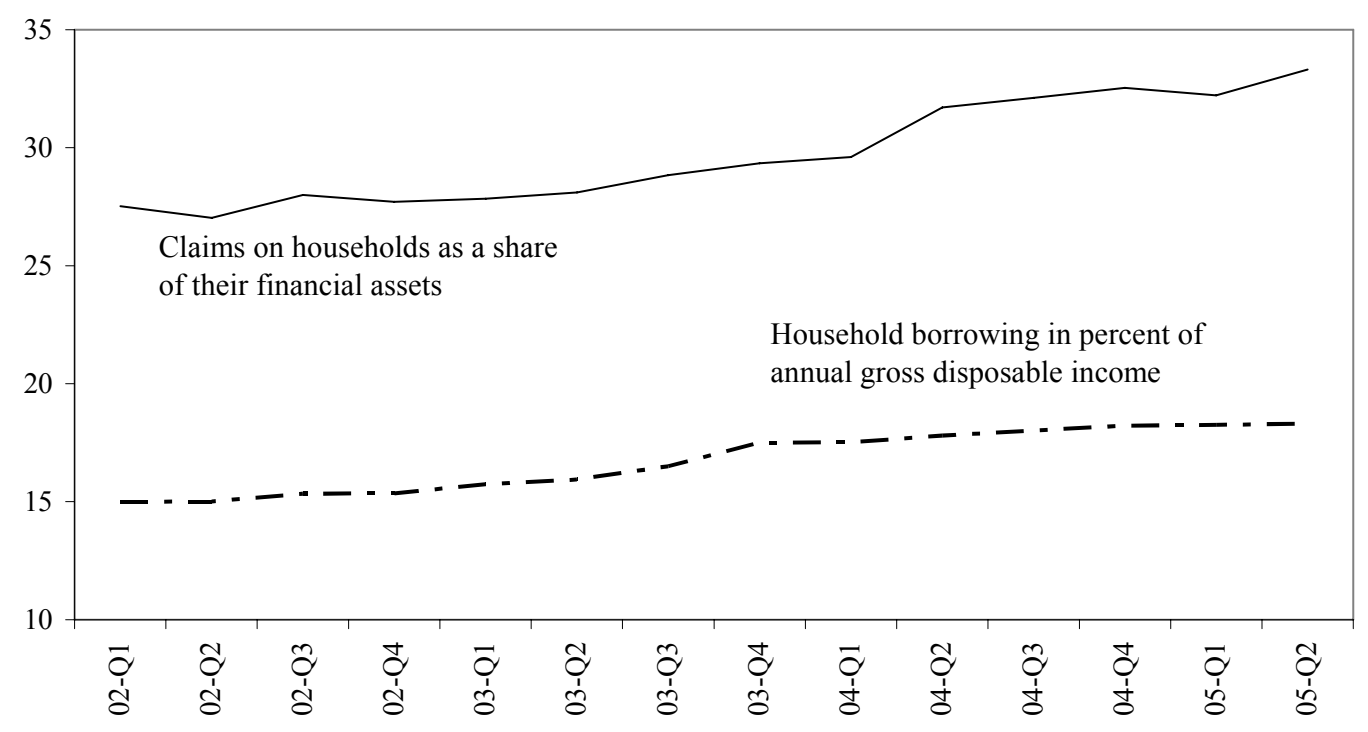

Source: Polish Statistical Office; and IMF staff estimates.

\section{Aggregate currency mismatches in household balance sheets also do not appear} excessive ${ }^{14}$ Households are unlikely to be able to borrow directly from nonresidents, and, hence, their external currency mismatches can be assumed to be negligible. Assuming conservatively that domestic foreign currency liabilities of households are unhedged and are not matched by their foreign currency assets, ${ }^{15}$ outstanding foreign currency liabilities of households to domestic banks can be used as a proxy for total currency mismatches in the balance sheet of the household sector. Foreign currency liabilities of households have risen from less than $1 \frac{1}{2}$ percent of GDP in 1996 to about 4 percent of GDP in 2005. As of now, the magnitude of the mismatch does not appear alarming (a 30 percent depreciation would raise it to $5 \frac{1}{2}$ percent of GDP), but needs to be monitored. As domestic interest rates converge further to the euro area levels, the interest rate differential on zloty- and foreign-currencydenominated loans should narrow, stabilizing currency mismatches. ${ }^{16}$

\footnotetext{
${ }^{14}$ The analysis of balance sheet mismatches in the nonfinancial private sector is constrained by the lack of data on foreign currency assets of households, and the lack of subsectoral breakdowns for the nonfinancial private sector in the international investment position data.

${ }^{15}$ Like in other NMS, households in Poland are likely to hold their wealth mostly in zloty-denominated nonfinancial assets (particularly, real estate). Most households are unlikely to be able to cover their exchange rate exposure through natural hedges, although some households might receive foreign currency-denominated remittances from members working abroad.

${ }^{16}$ The above analysis was constrained by data limitations. One would need to compile a full national balance sheet to get a complete picture of sectoral mismatches and inter-sectoral linkages.
} 


\section{Financial soundness indicators and stress tests}

\section{Macroprudential indicators suggest that the banking system is sound, liquid,} profitable, and well capitalized. Following a temporary deterioration in 2002-03, financial soundness indicators (FSIs) have been improving steadily in recent years and are broadly in line with those for its regional peers (Table 3). ${ }^{17}$ However, a regional comparison of an aggregate measure of bank soundness, distance to default, implies that the soundness of Polish banks has on average lagged behind banks in other central and eastern European countries (CEECs) and the Baltics in recent years. At the same time, the dispersion of distance to default in Poland has been the lowest among the NMS, however, implying greater homogeneity of bank soundness indicators than in other NMS.

Table 3. Poland: Financial Soundness Indicators for the Banking Sector, 1998-2005 (In percent)

\begin{tabular}{|c|c|c|c|c|c|c|c|c|}
\hline & 1998 & 1999 & 2000 & 2001 & 2002 & 2003 & 2004 & 2005 \\
\hline \multicolumn{9}{|l|}{ Capital adequacy } \\
\hline Regulatory capital to risk-weighted assets & 11.7 & 13.1 & 12.9 & 13.5 & 14.2 & 13.8 & 15.4 & 14.5 \\
\hline Regulatory Tier I capital to risk-weighted assets 1/ & 14.0 & 14.7 & 14.1 & 14.1 & 14.2 & 13.9 & 15.3 & 14.4 \\
\hline Capital to assets & 7.0 & 7.1 & 7.2 & 8.0 & 8.7 & 8.3 & 8.0 & 7.8 \\
\hline Classified loans net of provisions to capital 2/ & 33.2 & 54.3 & 59.4 & 58.9 & 63.6 & 68.7 & 36.8 & 21.4 \\
\hline Nonperforming loans net of provisions to capital 3/ & $\ldots$ & $\ldots$ & $\ldots$ & $\ldots$ & $\ldots$ & 31.1 & 22.5 & 11.9 \\
\hline \multicolumn{9}{|l|}{ Asset composition and quality } \\
\hline Classified loans to gross loans $2 /$ & 10.5 & 13.3 & 15.0 & 17.9 & 21.1 & 21.2 & 14.9 & 11.0 \\
\hline Nonperforming loans to gross loans 3 / & $\ldots$ & $\ldots$ & $\ldots$ & $\ldots$ & $\ldots$ & 10.4 & 9.2 & 7.7 \\
\hline \multicolumn{9}{|l|}{ Sectoral distribution of loans to total loans } \\
\hline Loan to households 4/ & 33.8 & 37.0 & 39.7 & 42.4 & 41.4 & 43.7 & 48.0 & 52.3 \\
\hline Loans to non-financial corporations 4/ & 66.2 & 63.0 & 60.3 & 57.6 & 58.6 & 56.3 & 52.0 & 47.7 \\
\hline \multicolumn{9}{|l|}{ Earnings and profitability } \\
\hline Return on average assets (after-tax) & 0.6 & 0.9 & 1.1 & 0.9 & 0.5 & 0.5 & 1.4 & 1.6 \\
\hline Return on average equity (after-tax) & 9.1 & 13.2 & 15.4 & 12.4 & 6.1 & 5.8 & 17.1 & 20.7 \\
\hline Interest margin to gross income 5 / & 70.3 & 63.7 & 60.8 & 53.3 & 54.4 & 55.7 & 56.4 & 57.7 \\
\hline Non-interest income (net) to gross income 6/ & 29.7 & 36.3 & 39.2 & 46.7 & 45.6 & 44.3 & 43.6 & 42.3 \\
\hline Noninterest expenses to gross income $7 /$ & 68.0 & 70.1 & 67.9 & 68.6 & 71.5 & 78.9 & 77.1 & 72.3 \\
\hline \multicolumn{9}{|l|}{ Liquidity } \\
\hline Liquid assets to total assets (liquid assets ratio) 8/ & 28.8 & 15.6 & 17.0 & 17.8 & 24.1 & 26.1 & 26.2 & 26.2 \\
\hline Liquid assets to borrowed funds $8 /$ & 32.7 & 17.7 & 19.2 & 20.2 & 27.4 & 29.5 & 29.8 & 29.6 \\
\hline \multicolumn{9}{|l|}{ Sensitivity to market risk } \\
\hline Net open positions in foreign exchange to capital & $\ldots$ & -1.5 & 5.3 & 2.1 & 1.1 & 0.3 & 1.5 & 2.5 \\
\hline
\end{tabular}

Source: National Bank of Poland.

1/ Tier 1 capital consists of core capital reduced by a shortfall in specific / impairment provisions.

2/ The definition of classified loans was changed in 2004.

3/ Nonperforming loans defined as arrears over 90 days.

4/ The definition of the sectors changed in 2002.

$5 /$ No deductions of income from other deposit takers.

6/ No deductions of expenses paid to other deposit takers.

7/ Noninterest expenses comprise fees and commission costs, other operating costs, depreciation, personnel costs, and other general expenses.

8/ Liquid assets comprise cash, balances at the NBP accounts, placements at banks maturing in up to 1 month, debt securities admitted to public trading, and units in open-ended investment funds. Borrowed funds are all liabilities other than provisions, capital, and earnings.

${ }^{17}$ A historically large stock of irregular loans in Poland partly reflects strict loan classification rules, which until 2004 were based on the 30 day rule rather than the 90 day rule, which is more common across the world. 
New Members States: Distance to Default of Commercial Banks, 1996-2004 1/

Mean

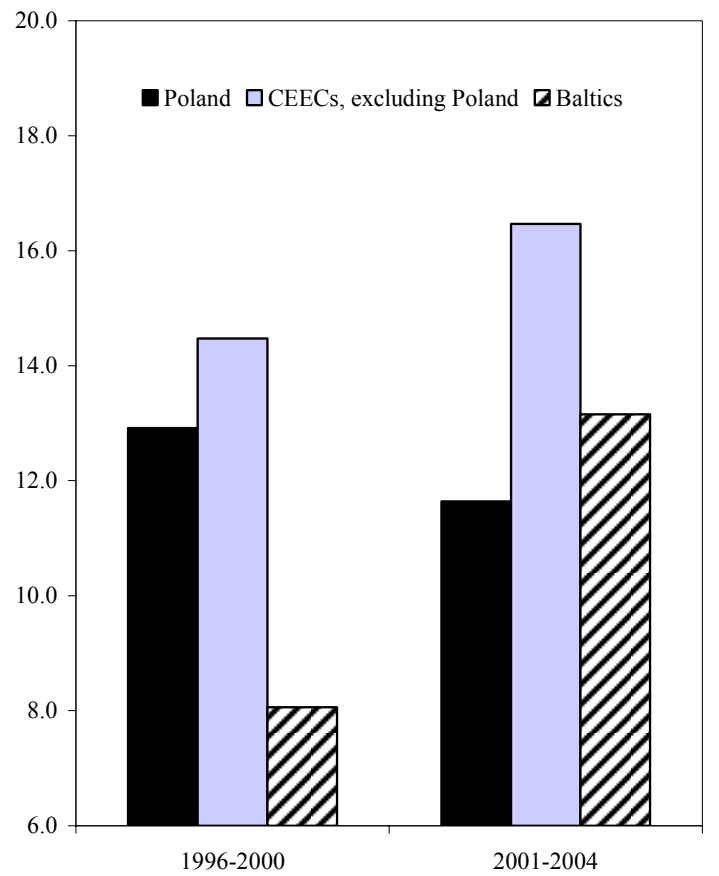

Standard Deviation

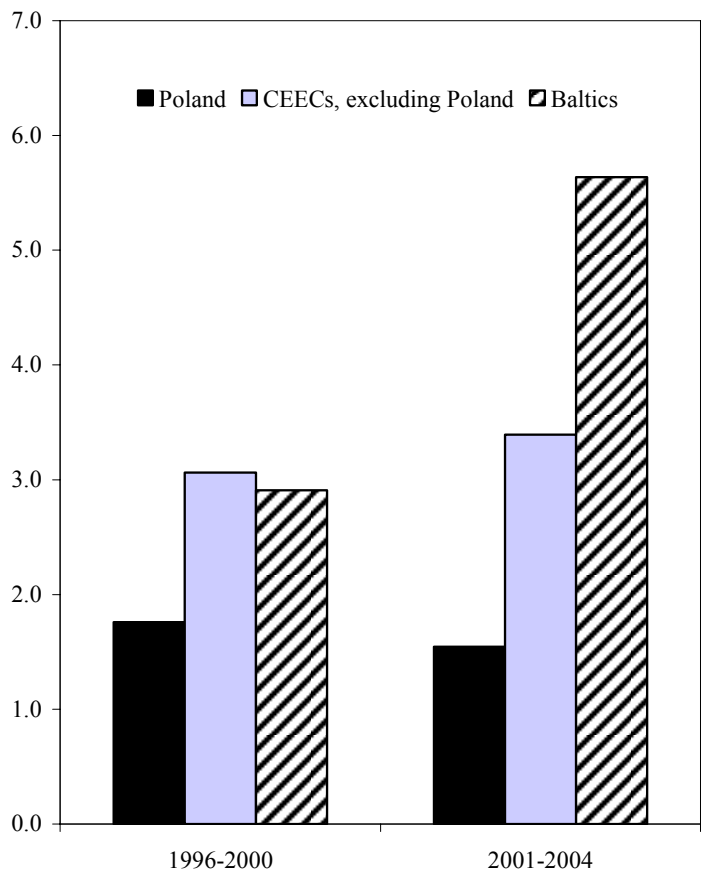

Source: Bankscope; IMF staff estimates.

1/ Distance to default measures the number of standard deviations a return realization would have to fall for equity to be depleted (see Box 1 for more details). The Central and Eastern European countries include the Czech Republic, Hungary, Poland, Slovak Republic, and Slovenia. The Baltic countries include Estonia, Latvia, and Lithuania.

25. Market indicators for Polish banks are also generally positive, but ratings are lagging behind some CEEC peers. Polish banking stock prices have grown rapidly in recent years, faster than the general Polish stock market index. ${ }^{18}$ Fitch's Banking System Indicator (BSI) ranks Poland the same as Hungary, Latvia, Lithuania, and the Slovak Republic, but below the Czech Republic, Estonia, and Slovenia. ${ }^{19}$ Financial strength ratings by Moody's are lower for Polish banks than for their CEEC peers, in line with the distance-to-default measures.

\section{Stress tests carried out by the Polish authorities during the FSAP Update} suggested that Polish banks would be able to withstand a major increase in credit risk associated with housing loans. ${ }^{20}$ The most relevant stress tests in an environment of rapid

\footnotetext{
${ }^{18}$ For example, at the Warsaw Stock Exchange, the WIG-Banking index has increased on average by 32 percent per annum between end-1998 and mid-2006, compared with about 23 percent for the WIG general index.

${ }^{19}$ See Fitch Ratings (2005a, c) and Moody's Investor Service (2005). The BSI measures intrinsic bank systemic risk on a scale of A (very high quality) to E (very low quality). Poland's BSI ranking is D (low quality).

${ }^{20}$ For more details, see the accompanying Technical Note on Stress Testing of the Banking System.
} 
credit growth are those based on satisfactory and special mention loans, as any worsening in the new loans will be first seen in these categories. If about one fifth of loans classified as satisfactory and special mention were to migrate to doubtful (a major shock, compared to historical experiences), capital adequacy ratios would drop to 8 percent in banks with assets representing about one fifth of total banking sector assets. If 10 percent of performing foreign currency loans to households became classified, banking sector capital would decline only by about 2 percent, and all banks would remain solvent. The results of interbank contagion stress tests suggest that contagion through the interbank market currently does not present a systemic risk: a random failure of a bank is expected to result in only very small losses as a percent of total banking system assets. ${ }^{21}$

\section{Poland-specific econometric modeling of credit risk}

\section{An econometric model of default risk using aggregate data for Poland suggests} that the exchange-rate related credit risk is currently low (Table 4). The regression models default risk on corporate and household loans (measured as the share of nonperforming loans in total outstanding corporate or household loans) as a function of various macroeconomic variables, such as industrial production, real wages, unemployment rate, real effective exchange rate, and real interest rates. The results show that credit risk in the household sector is negatively correlated with exchange rate depreciation, possibly because, in the event of exchange rate depreciation, the increase in household incomes, reflecting greater competitiveness and higher economic growth, tends to compensate for the increased debt-service payments on foreign currency-indexed loans. Variables proxying economic growth and income indeed seem to be the most important determinants of credit risk relating to household and corporate loans. One caveat for interpreting these results is that the above analysis uses monthly data on classified loans, while Polish banks review their portfolios quarterly.

\section{Another reason for caution is that these results are based on aggregate data,} which do not take into account the distribution of risks across banks. Even if the aggregate risks associated with the rapid growth of foreign currency lending to households seem low, the exposures of individual banks might be significant. The business strategies of foreign-owned banks for foreign currency lending in Poland have differed, in part reflecting differences in their experiences with this type of lending in their home markets (Box 2). Some banks have restricted foreign currency lending through internal policies, while others have aggressively expanded foreign currency lending to gain market shares. The share of foreign currency loans in portfolios of some banks has increased sharply in recent years. ${ }^{22}$

\footnotetext{
${ }^{21}$ See the accompanying Technical Note on Stress Testing of the Banking System.

${ }^{22}$ Fitch Ratings (2005a and 2005c).
} 
Table 4. Modeling the Probability of Default on Corporate and Household Bank Loans in Poland

\begin{tabular}{|c|c|c|c|c|c|}
\hline \multicolumn{3}{|c|}{$\underline{\text { Corporates }}$} & & \multicolumn{2}{|c|}{$\underline{\text { Households }}$} \\
\hline & Coefficient & Probability & & Coefficient & Probability \\
\hline DNPLRTC_12 & 0.45 & 0.00 & DNPLRTH_6 & 0.27 & 0.00 \\
\hline Dip_8 & -5.08 & 0.01 & DNPLRTH_7 & 0.33 & 0.00 \\
\hline Dip_9 & -6.15 & 0.00 & DNPLRTH_8 & -0.25 & 0.00 \\
\hline Dip_10 & -5.11 & 0.00 & DNPLRTH_9 & -0.13 & 0.12 \\
\hline Dwr_11 & 8.25 & 0.00 & DNPLRTH_10 & 0.17 & 0.05 \\
\hline \multirow[t]{12}{*}{ DRUP_2 } & 0.81 & 0.00 & Dip_1 & -1.37 & 0.13 \\
\hline & & & Dip_6 & -3.65 & 0.00 \\
\hline & & & Dip_8 & -1.16 & 0.20 \\
\hline & & & Dwr_6 & -3.46 & 0.03 \\
\hline & & & DRUP_3 & 0.26 & 0.02 \\
\hline & & & DRUP_10 & 0.27 & 0.02 \\
\hline & & & DRPR_2 & 0.06 & 0.11 \\
\hline & & & DRPR_8 & 0.09 & 0.01 \\
\hline & & & DRPR_9 & 0.05 & 0.13 \\
\hline & & & Dreer_2 & 3.51 & 0.00 \\
\hline & & & Dreer_7 & -3.09 & 0.01 \\
\hline & & & Dreer_9 & 3.43 & 0.01 \\
\hline Observations & 96 & & Observations & 96 & \\
\hline Adjusted R-squared & 0.44 & & Adjusted R-squared & 0.51 & \\
\hline \multicolumn{6}{|l|}{ Specification tests } \\
\hline & Statistic & Probability & & Statistic & Probability \\
\hline Chow test: & 0.81 & 0.61 & Chow test: & 0.89 & 0.54 \\
\hline AR 1-4 test: & 0.33 & 0.86 & AR 1-4 test: & 0.20 & 0.94 \\
\hline ARCH 1-4 test: & 0.66 & 0.62 & ARCH 1-4 test: & 0.29 & 0.88 \\
\hline Heteroskedasticity test: & 0.51 & 0.90 & Heteroskedasticity test: & 1.49 & 0.11 \\
\hline \multicolumn{6}{|c|}{ Static Long-Run Equation 2/ } \\
\hline & Coefficient & Probability & & Coefficient & Probability \\
\hline Dip & -29.51 & 0.01 & Dip & -10.07 & 0.00 \\
\hline Dwr & 14.90 & 0.00 & Dwr & -5.64 & 0.05 \\
\hline DRUP & 1.46 & 0.00 & DRUP & 0.87 & 0.00 \\
\hline DRPR & - & - & DRPR & 0.34 & 0.02 \\
\hline Dreer & - & - & Dreer & 6.28 & 0.10 \\
\hline \multicolumn{4}{|l|}{$\underline{\text { Sensitivity Analysis }}$} & \multicolumn{2}{|c|}{$\underline{\text { Change in NPL ratio }}$} \\
\hline & Mean & Stand. Deviation & 1 STD Adverse Shock & Corporates & Households \\
\hline Dip & 0.005 & 0.03 & -0.03 & 0.89 & 0.31 \\
\hline Dwr & 0.004 & 0.02 & 0.02 & 0.33 & 0.13 \\
\hline DRUP & 0.078 & 0.27 & 0.34 & 0.50 & 0.30 \\
\hline DRPR & -0.079 & 0.79 & 0.71 & - & 0.24 \\
\hline Dreer & 0.002 & 0.02 & 0.03 & - & - \\
\hline
\end{tabular}

Source: National Bank Poland, Polish Statistical Office, and IMF staff estimates.

1/ The dependent variables are nonperforming loans as a share of total outstanding corporate and household loans, respectively (denoted by NPLRTC and NPLRTH). Explanatory variables include industrial production (ip), real average gross wages (wr), unemployment rate (RUP), real effective exchange rate (reer), and policy rate in real terms (RPR). "D" denotes a one-period difference, and lower case letters indicate logarithms. A positive change in the real effective exchange rate indicates appreciation. The model was estimated using the OLS method on a sample from January 1998 to December 2005. Parsimonious dynamic models for the nonperforming loan ratios were obtained using general-to-specific modeling, starting with 12 lags for all variables.

2 / DNPLRTC or DNPLRTH $=\beta 1+\beta 2 *$ Dip $+\beta 3 *$ Dwr $+\beta 4 *$ DRUP $+\beta 5 *$ DRPR $+\beta 6 *$ Dreer. Constant is not reported. A dash indicates that the variable is statistically insignificant and is not included in the long-run solution. 


\section{Box 2. How Experiences in Home Countries Have Affected Foreign Banks' Strategies for Foreign Currency Mortgage Lending in the NMS}

Reflecting different experiences in home countries, Italian-owned banks have generally been more cautious in offering foreign currency mortgages through their CEEC subsidiaries; Austrian banks have been promoting such mortgages aggressively in the CEECs (Fitch, 2005c).

In Italy, exchange rate depreciation in the early 1990s wreaked havoc on the country's mortgage market, saddling borrowers with higher loan payments. There were no major bank failures, but banks suffered a serious reputational damage, and have become very averse to mortgage lending in foreign currency.

In Austria, experiences with foreign currency mortgage lending have been more positive. Nonetheless, the Financial Sector Stability Assessment (FSSA) for Austria (IMF, 2005a) noted that foreign currency lending by banks to domestic customers is unusually prevalent in Austria, especially for house mortgages, and while the risks are well understood and managed by the banks (and the system is "generally sound and resilient"), many borrowers are not hedged. The report suggested continuing efforts to educate customers and ensure that banks - particularly the smaller ones_-further improve their risk management.

\section{Cross-country econometric analysis using bank-level data}

29. Rapidly expanding foreign currency housing lending does not seem to have come at the expense of financial soundness. A graphical analysis of publicly available bank-level data on total outstanding loans suggests that rapidly expanding Polish banks are financially sound. ${ }^{23}$ Although there does not seem to be a strong relationship between credit growth and capital adequacy at the individual bank level, credit growth in banks with a high share of irregular loans has been slow. Plotting distance to default vis-à-vis bank credit growth also does not suggest that rapid credit growth has been associated with weaknesses in individual banks. ${ }^{24}$ A similar analysis using detailed supervisory data on foreign currency lending by all Polish banks was conducted by the Polish authorities during the FSAP Update. It rendered similar conclusions: banks actively engaged in foreign currency lending are well capitalized and sound. A small negative correlation was found between measures of foreign currency

\footnotetext{
${ }^{23}$ These bank-level data are from the Bankscope database, which provides balance sheet and income account data for about 60 percent of all commercial banks, accounting for about 85 percent of total banking system assets. The data set comprises large, medium, and small banks; and domestically and foreign-owned banks, and, hence, is fairly representative.

${ }^{24}$ There is one exception (not shown in the chart): a small domestically owned bank, which has been expanding its loan portfolio rapidly, even though irregular loans account for about half of its loan portfolio. The bank might have been slow to write off these loans because of tax reasons.
} 
lending (the share of foreign currency loans in bank loan portfolio and the annual percent change in foreign currency loans) and measures of bank soundness (distance to default and the capital-adequacy ratio), but this correlation was statistically insignificant.

Poland: Bank Credit Growth, Capital Adequacy, and Irregular Loans 1/ (In percent)
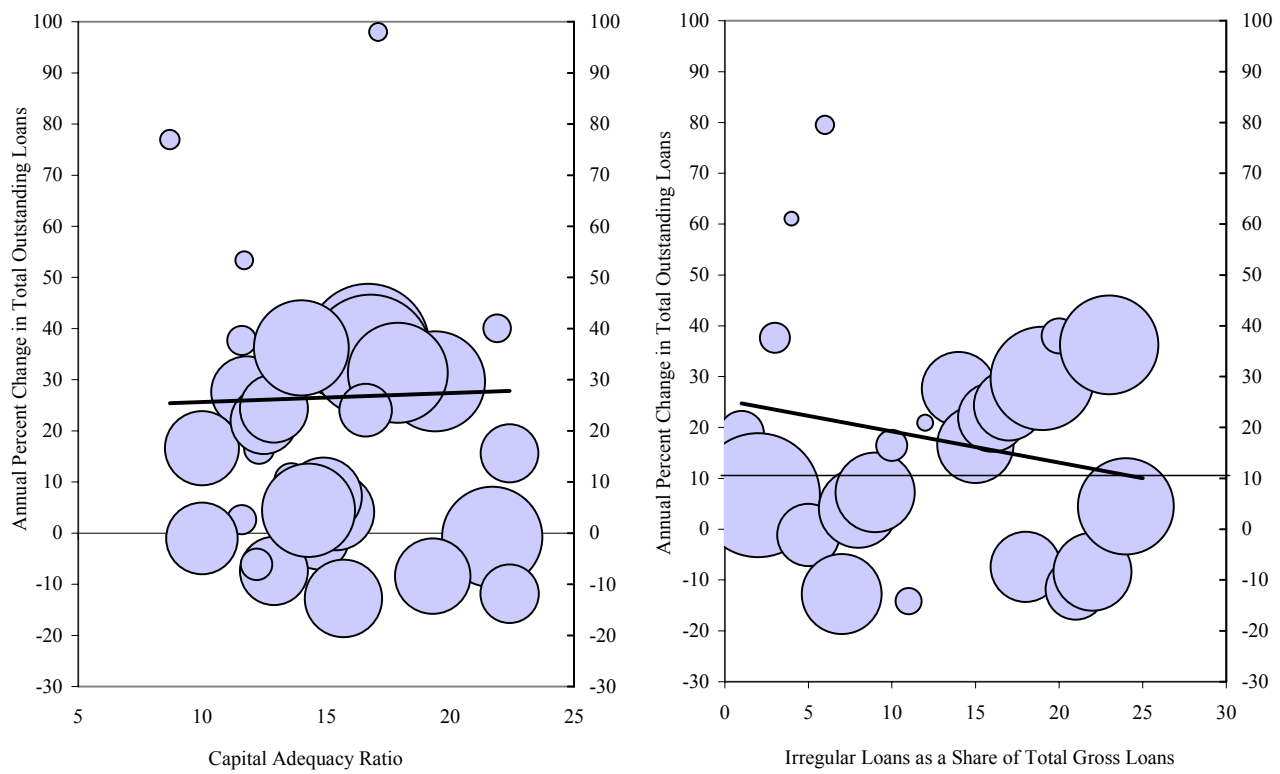

Sources: Bankscope; and IMF staff estimates.

1/ Data refer to 2005 or 2004, depending on data availability for individual banks. Each bubble represents a banking institution, and the bubble size reflects the bank's total assets in U.S. dollars. The black line indicates a linear trend.

Poland: Bank Credit Growth and Distance to Default, 2004

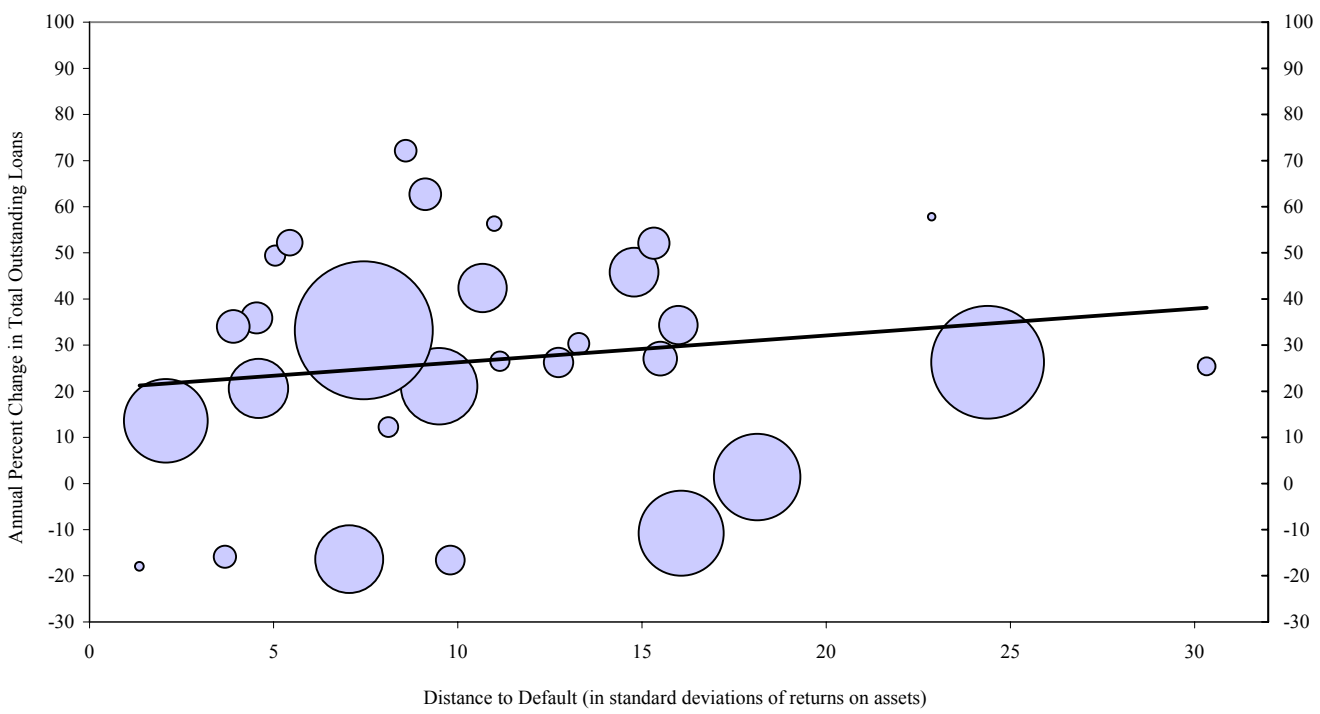

Sources: Bankscope; and IMF staff estimates.

1/ Data refer to 2004. Each bubble represents a banking institution, and the bubble size reflects the bank's total assets in U.S. dollars. The black

line indicates a linear trend. 
30. The cross-country econometric analysis using publicly available bank-level data for the NMS shows that, in Poland, stronger banks have been expanding more rapidly in recent years and credit growth has not had any apparent negative effect on bank soundness. ${ }^{25}$ The coefficient on distance to default in the equation for bank credit growth in Poland was positive and statistically significant in 2001-04, in contrast to other NMS, where rapid credit growth seems to have become broad-based and independent of bank soundness during that period (Table 2, Column 7). Like in other NMS, recent credit growth in Poland does not seem to have weakened banks (Table 2, Column 8). These results are robust using the sample of Polish banks only. The soundness of Polish banks in recent years has been positively correlated with economic growth, real interest rates, bank profitability and liquidity, and negatively correlated with the level of economic and institutional development (proxied by GDP per capita); exchange rate depreciation does not seem to have had any significant impact on bank soundness in recent years (Table 5, Column 2).

31. Financial risks in banks with large and rapidly expanding foreign currency loan portfolios do not seem statistically different from those in other banks: loan growth in banks with large and rapidly growing foreign currency loan portfolios seems to have been positive correlated with bank soundness (that is, sounder banks are expanding at a faster rate) (Table 5, Column 3), and loan growth in such banks has not had any identifiable effect on bank soundness so far (Table 5, Column 4). The same result holds for banks with large and rapidly growing household loan portfolios (Table 5, Columns 5-6). There is one difference, however: banks with large and rapidly growing household loan portfolios seem to be generally weaker than other Polish banks (the coefficient on the dummy variable identifying such banks is negative and statistically significant in Table 5, Column 6), while banks with large and rapidly growing foreign currency loan portfolios seem to be just as sound as other Polish banks (the coefficient on the dummy variable identifying such banks is statistically insignificant in Table 5, Column 4). This finding implies that banks with large and rapidly growing household credit exposures require close supervisory attention independent of the currency of their loan denomination.

${ }^{25}$ For more details, see the Technical Note "Credit, Growth and Financial Stability." 
Table 5. Modeling Credit Growth and Bank Soundness in Poland, 2001-04

\begin{tabular}{|c|c|c|c|c|c|c|}
\hline & \multicolumn{2}{|c|}{ Total Credit } & \multicolumn{2}{|c|}{ Foreign Currency Credit } & \multicolumn{2}{|c|}{ Household Credit } \\
\hline & $\begin{array}{l}\text { Equation 1: Bank } \\
\text { Credit Growth } \\
\text { (1) }\end{array}$ & $\begin{array}{l}\text { Equation 2: Distance to } \\
\text { Default } \\
\text { (2) }\end{array}$ & $\begin{array}{c}\text { Equation 1: Bank Credit } \\
\text { Growth } \\
\text { (3) }\end{array}$ & $\begin{array}{c}\text { Equation 2: Distance to } \\
\text { Default } \\
\text { (4) }\end{array}$ & $\begin{array}{c}\text { Equation 1: Bank Credit } \\
\text { Growth } \\
(5)\end{array}$ & $\begin{array}{c}\text { Equation 2: Distance to } \\
\text { Default } \\
\text { (6) }\end{array}$ \\
\hline Bank credit growth (lagged) & $\begin{array}{r}0.142^{* *} \\
{[2.03]}\end{array}$ & $\begin{array}{r}-0.007 \\
{[0.82]}\end{array}$ & $\begin{array}{r}0.121^{*} \\
{[1.80]}\end{array}$ & $\begin{array}{r}-0.013 \\
{[1.49]}\end{array}$ & $\begin{array}{r}0.149^{* *} \\
{[2.43]}\end{array}$ & $\begin{array}{r}-0.008 \\
{[1.03]}\end{array}$ \\
\hline Distance to default (lagged) & $\begin{array}{r}1.137 * * * \\
{[3.48]}\end{array}$ & $\begin{array}{r}0.868^{* * * *} \\
{[21.60]}\end{array}$ & $\begin{array}{r}1.429 * * * \\
{[4.08]}\end{array}$ & $\begin{array}{r}0.914 * * * \\
{[20.87]}\end{array}$ & $\begin{array}{r}1.423 * * * \\
{[4.17]}\end{array}$ & $\begin{array}{r}0.906 * * * \\
{[21.26]}\end{array}$ \\
\hline Distance to default of banks with large and rapidly growing FX loans (lagged) & & & $\begin{array}{r}24.172 \\
{[0.91]}\end{array}$ & & & \\
\hline Distance to default of banks with large and rapidly growing household loans (lagged) & & & & & $\begin{array}{c}0.282 \\
{[0.05]}\end{array}$ & \\
\hline Real GDP growth (lagged) & $\begin{array}{c}4.142 \\
{[0.66]}\end{array}$ & $\begin{array}{r}1.590 * * \\
{[2.06]}\end{array}$ & $\begin{array}{r}3.342 \\
{[0.52]}\end{array}$ & $\begin{array}{r}0.575 \\
{[0.72]}\end{array}$ & $\begin{array}{r}6.198 \\
{[1.05]}\end{array}$ & $\begin{array}{r}0.985 \\
{[1.34]}\end{array}$ \\
\hline GDP per capita (lagged) & $\begin{array}{l}-0.322 \\
{[0.40]}\end{array}$ & $\begin{array}{r}-0.224 * * \\
{[2.26]}\end{array}$ & $\begin{array}{r}-0.499 \\
{[0.63]}\end{array}$ & $\begin{array}{c}-0.154 \\
{[1.54]}\end{array}$ & $\begin{array}{l}-0.661 \\
{[0.88]}\end{array}$ & $\begin{array}{r}-0.178^{*} \\
{[1.91]}\end{array}$ \\
\hline Real interest rate (lagged) & $\begin{array}{l}-0.321 \\
{[0.08]}\end{array}$ & $\begin{array}{r}0.961 * * \\
{[1.97]}\end{array}$ & $\begin{array}{r}-0.936 \\
{[0.23]}\end{array}$ & $\begin{array}{r}0.244 \\
{[0.47]}\end{array}$ & $\begin{array}{c}1.412 \\
{[0.38]}\end{array}$ & $\begin{array}{l}0.613 \\
{[1.33]}\end{array}$ \\
\hline Real exchange rate depreciation (lagged) & $\begin{array}{r}-23.528 \\
{[1.03]}\end{array}$ & $\begin{array}{l}-2.121 \\
{[0.75]}\end{array}$ & $\begin{array}{r}-13.606 \\
{[0.60]}\end{array}$ & $\begin{array}{r}-6.526^{* *} \\
{[2.30]}\end{array}$ & $\begin{array}{l}-1.479 \\
{[0.07]}\end{array}$ & $\begin{array}{r}-4.001 \\
{[1.53]}\end{array}$ \\
\hline Net interest margin (lagged) & $\begin{array}{r}3.233 * * * \\
{[3.31]}\end{array}$ & $\begin{array}{r}0.248^{* *} \\
{[2.06]}\end{array}$ & $\begin{array}{r}5.887 * * * \\
{[3.70]}\end{array}$ & $\begin{array}{r}0.545 * * * \\
{[2.74]}\end{array}$ & $\begin{array}{r}3.411 * * * \\
{[3.79]}\end{array}$ & $\begin{array}{r}0.251^{* *} \\
{[2.22]}\end{array}$ \\
\hline Cost-to-income ratio (lagged) & $\begin{array}{l}-0.001 \\
{[0.01]}\end{array}$ & $\begin{array}{r}0.013 \\
{[1.03]}\end{array}$ & $\begin{array}{r}0.046 \\
{[0.46]}\end{array}$ & $\begin{array}{r}0.031^{* *} \\
{[2.50]}\end{array}$ & $\begin{array}{l}-0.003 \\
{[0.04]}\end{array}$ & $\begin{array}{r}0.022^{*} \\
{[1.91]}\end{array}$ \\
\hline Liquidity ratio (lagged) & $\begin{array}{r}-0.442^{* *} \\
{[1.99]}\end{array}$ & $\begin{array}{r}0.095^{* * *} \\
{[3.48]}\end{array}$ & $\begin{array}{r}-0.508^{* *} \\
{[2.37]}\end{array}$ & $\begin{array}{r}0.075^{* * *} \\
{[2.81]}\end{array}$ & $\begin{array}{r}-0.515^{* * *} \\
{[2.41]}\end{array}$ & $\begin{array}{r}0.068^{* * *} \\
{[2.52]}\end{array}$ \\
\hline Foreign ownership & $\begin{array}{r}0.083 \\
{[1.39]}\end{array}$ & $\begin{array}{l}-0.011 \\
{[1.49]}\end{array}$ & $\begin{array}{r}0.114^{*} \\
{[1.85]}\end{array}$ & $\begin{array}{r}0.003 \\
{[0.35]}\end{array}$ & $\begin{array}{l}0.077 \\
{[1.34]}\end{array}$ & $\begin{array}{l}-0.001 \\
{[0.20]}\end{array}$ \\
\hline Banks with large and rapidly growing FX loans & & & $\begin{array}{r}-270.268 \\
{[0.88]}\end{array}$ & $\begin{array}{r}10.549 \\
{[0.63]}\end{array}$ & & \\
\hline Banks with large and rapidly growing household loans & & & & & $\begin{array}{r}1.872 \\
{[0.03]}\end{array}$ & $\begin{array}{r}-3.721^{* *} \\
{[2.18]}\end{array}$ \\
\hline Credit growth through banks with large and rapidly growing FX loans (lagged) & & & & $\begin{array}{l}-0.626 \\
{[0.53]}\end{array}$ & & \\
\hline Credit growth through banks with large and rapidly growing household loans (lagged) & & & & & & $\begin{array}{r}0.134^{*} \\
{[1.82]}\end{array}$ \\
\hline Observations & 96 & 96 & 81 & 81 & 81 & 81 \\
\hline R-squared & 0.36 & 0.84 & 0.42 & 0.87 & 0.44 & 0.87 \\
\hline
\end{tabular}

Sources: Bankscope; IMF's International Financial Statistics; and IMF staff estimates.

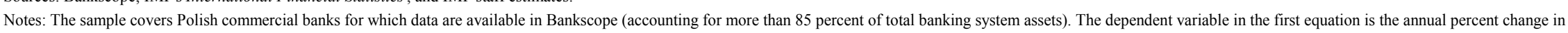

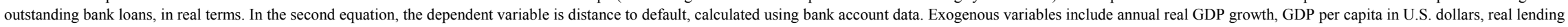

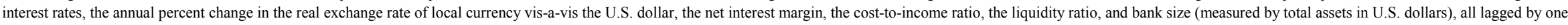

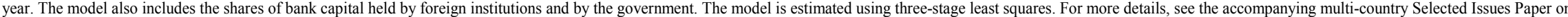
Export Structure and Credit Growth. 


\section{Policy Response to Rapid Growth of Foreign Currency Credit}

\section{A. Lessons from Cross-Country Experiences}

\section{Experiences of other European countries where housing lending in foreign} currency has been popular (for example, Austria, Ireland, and Italy) provide limited guidance for Poland. Although some banks suffered significant reputational damage when exchange rates depreciated, actual losses from exchange rate-related credit risk were fairly small in these countries, largely because exchange rate depreciation did not persist for long (Box 2). However, the fact that ex post losses turned out to be small does not imply that $a$ priori risks had been negligible. A priori risks might well be even larger in Poland, because legal and risk management frameworks in Poland are likely to be weaker than in the industrial countries in question and foreclosure practices in Poland have largely been untested, given the short lending history in this country.

\section{A broader analysis of cross-country experiences suggests that encouraging} proper credit assessment and risk management by banks and individuals is a policy priority in an environment of rapid credit growth. Countries have used a variety of supervisory, regulatory and administrative measures to manage rapid credit growth in foreign currency (Appendix). A detailed analysis of country experiences by Hilbers and others (2005), suggests that these measures are likely to be most effective when implemented as part of a broad policy package that addresses regulatory flaws, strengthens supervision and introduces institutional arrangements for market infrastructure to ensure sound lending growth. In some cases, it might not be possible to limit foreign currency lending through regulation alone, for example, if incentives for such lending reflect macroeconomic factors. Attempts to do so might encourage circumvention, for example, by moving business offshore or to the nonbank sector. If risks from rapid growth in foreign currency lending are localized and concentrated in individual institutions, enhanced supervision of such institutions would be the best way to address such risks, without increasing regulatory burden. However, in cases when addressing the underlying macroeconomic imbalances is not feasible and there are significant risks to financial and/or macroeconomic stability, there might still be a case for using regulatory measures as a second-best response. Preference should be given to riskbased regulatory measures, in conjunction with strengthening supervision.

\section{B. Policy Response in Poland}

\section{The Polish authorities have already taken several steps to address the risks} associated with rapid growth in foreign currency lending. In 2005, the Commission for Banking Supervision (CBS) increased the risk weight on housing loans with loan-to-value ratios exceeding 50 percent to 100 percent (from 50 percent previously, which had been consistent with prevalent international practice) ${ }^{26}$ Subsequently, the CBS introduced new

\footnotetext{
${ }^{26}$ The weight remains at 50 percent for loans with LTV ratios below 50 percent.
} 
prudential recommendations for lending in foreign currency, which came into effect in July 2006. These recommendations aimed at further improving risk management and disclosure in line with good international practices. The CBS recommended that banks strengthen default risk assessments, conduct regular stress tests for the mortgage portfolio, and better inform borrowers about exchange rate exposures. Next, the authorities intend to follow up on these recommendations in the course of the regular on-site and off-site supervisory process. The authorities also indicated that they stand ready to introduce additional, quantitative restrictions on foreign currency lending, if necessary.

\section{Staff's analysis presented in this paper does not point to any specific evidence} that would suggest the need for introducing administrative regulations aimed at slowing foreign currency credit growth. The analysis implies the need for ensuring sound credit assessment and risk management practices, especially in banks actively engaged in foreign currency and household lending. Based on the econometric and other analyses discussed above, the risks from rapid credit growth seem localized and concentrated in individual institutions and are contained. Hence, an enhanced supervision of weaker institutions would be the best way to address such risks, without increasing the overall regulatory burden on the banking sector. Regulatory measures to restrict foreign currency housing lending risk being particularly counterproductive in Poland, as they might further slow the pace of financial deepening, drive business offshore or to the nonbank sector. With interest rates expected to converge to the euro-zone levels in the coming years, incentives for foreign-currency lending are likely to diminish naturally.

\section{Conclusions}

36. An econometric comparison of Poland's credit growth experiences with those in other NMS suggests that, without continued improvements in the institutional framework for sound lending, Poland will continue to lag behind other NMS in financial deepening. Slow credit growth reflects not only slow economic growth in recent years and the efforts to improve banks' balance sheets in the beginning of this decade, but also institutional and structural factors. Further improvements in process-related aspects of collateral enforcement, the quality of company accounting and auditing, and the availability of reliable information on prospective corporate borrowers are needed to foster financial development and maximize Poland's economic potential.

\section{A broad-based statistical and econometric analysis of financial and household} balance sheet data implies that exchange rate-related credit risk and liquidity risk are currently contained. Although lagging behind other NMS, financial soundness and market indicators for Polish banks are generally favorable. Household indebtedness and currency mismatches do not seem excessive at the aggregate level, and the econometric analysis suggests that the main source of credit risk is the overall state of the economy rather than the exchange rate. Bank-level analyses show that rapid credit growth has been concentrated in relatively sound banks and has not weakened bank soundness so far. 
38. The above findings do not point to a strong policy case for introducing administrative restrictions aimed at reducing the overall rate of foreign currency and/or housing credit growth. Overly intrusive regulatory measures in this area might simply drive business offshore or to the nonbank sector, which would increase supervisory challenges without necessarily reducing the associated risks.

39. Rapid growth of foreign currency loans puts a premium on sound lending practices and risk management and effective supervision. Supervisors need to remain vigilant to any signs of weakening in credit standards, rising loan-to-value ratios, and an excessive concentration of risk. The main objective is to ensure that all banks have adequate credit assessment and risk management systems in place and disclose sufficient information to customers, for them to be fully aware of the risks associated with foreign currency borrowing. Continued strengthening of financial sector surveillance is also important, including improvements in stress testing and credit risk modeling, using disaggregated data on foreign currency loans and household balance sheets. 


\section{Appendix. Country Experience with Measures to Address Risks Associated with Foreign Currency Lending}

40. This appendix illustrates a range of regulatory, supervisory, and administrative measures that authorities in different countries have used to limit risks associated with rapid growth in foreign currency credit. ${ }^{27}$ Although the focus is on measures aimed to control risks arising from foreign currency loans, country experiences suggest that for these measures to be most effective they need to be implemented as a part of a broader policy package aimed to create a proper regulatory and institutional framework supporting sound credit growth.

41. Assessing the effectiveness of these policy measures is difficult for two reasons. First, most measures have been adopted fairly recently, and their impact is unlikely to be apparent in statistics yet. Second, most measures have been often adopted as a part of a broader policy package, which makes differentiating the impact of individual measures on credit volume and credit quality difficult.

42. Measures below are ordered broadly by their degree of restrictiveness, starting from the least invasive measures and moving to direct intervention in credit operations:

- Improved monitoring of exposures. In a number of countries (for example, Croatia, Hungary, and Romania), supervisors have stepped up their efforts to ensure that banks adequately monitor the extent of unhedged foreign exchange exposures of their borrowers, and that they properly manage the associated credit risk. These efforts included improvements in off-site tools (new or extended reporting forms, or targeted surveys) and increased focus on borrowers' foreign exchange exposures during on-site inspections.

- Better disclosure of risks to customers. Supervisory authorities in Hungary, for example, required banks (from January 2005) to specify the risks to which their borrowers are exposed to in the contracts for mortgage loans in foreign currency. Banks are also required to disclose their interest rate charges (APRC) on foreign currency loans, which have improved transparency and comparability for borrowers, given that all related fees are included in the calculation of the APRC. Information on foreign currency risks has also been included on the web page of the financial supervisory authority. ${ }^{28}$

\footnotetext{
${ }^{27}$ Hilbers and others (2005) include a general survey of measures countries used to address rapid credit growth. Some of these more general measures are likely to affect domestic currency credit rather than foreign currency credit. In this survey, we focus on measures geared toward loans in foreign exchange.

${ }^{28}$ A recent FSAP Update on Hungary commended these steps, but suggested that more can be done, such as requiring that loan applicants are provided with information on the scale of possible increases in mortgage payments under an unfavorable exchange rate scenario (see IMF, 2005b).
} 
- $\quad$ Raising public awareness. Central banks in countries with rapidly growing credit often highlight credit risks in their financial stability reports and other reports and public statements. Greece, Norway, and Spain in the late 1990s are examples of countries where rapid housing credit growth led to an increased attention by supervisors and central banks to monitoring of banks' activities, notably their credit management processes through stress testing and scenario analysis, and to enhancing market discipline through greater public disclosure. For instance, the Spanish authorities are closely monitoring forward-looking indicators of potential debtservicing difficulties, placing emphasis on continued vigilance, accompanied by moral suasion, to ensure that credit institutions exercise adequate caution and put effective credit approval and monitoring processes in place.

- $\quad$ Limiting incentives to borrow. For example, the authorities in Estonia recently reduced mortgage interest deductibility to address the rise in households' real estaterelated borrowing, with plans for further reductions in deductibility.

- $\quad$ Stricter enforcement of prudent risk management practices. Supervisors need to ensure in their on-site and off-site work that that credit risks from unhedged foreign currency-denominated or indexed loans are properly managed by banks. For example, in Croatia, supervisors issued guidelines to banks requiring them to (i) set up and maintain a comprehensive system of ongoing identification, measuring, monitoring, and controlling of currency-induced credit risk; (ii) develop a reliable system for granting loans exposed to the currency-induced credit risk; (iii) adequately manage the relationship between risk and the price of such loans; (iv) have in place a system of ongoing monitoring of this risk; and (v) develop adequate methods for management of this risk and build them into their credit policies and procedures.

- Higher risk weights. The higher risk weights for foreign currency loans imply higher capital requirements for banks that are involved more actively in this type of lending. For example, in Croatia, the authorities recently increased the risk weight of unhedged foreign currency-denominated and indexed loans by 25 percentage points. All such loans extended to debtors with foreign exchange assets covering less than 80 percent of their foreign exchange liabilities are considered unhedged. Ireland has recently raised risk weights on mortgage loans. Effective May 2006, for mortgage loans with LTVs above 80 percent, a risk weight of 100 percent applies to the portion of the loan exceeding this threshold. In Estonia, the authorities recently increased the risk weighting from 50 percent to 100 percent in the capital adequacy calculation of all loans secured by mortgages on residential property. At the same time, the authorities asked all regulators of foreign banks with established branches in Estonia to consider the possibility of applying a 100 percent risk weighting to all loans secured by mortgages on residential property granted to the residents of Estonia in their calculations of capital adequacy, to promote the level-playing field for all market participants. Also, all credit institutions in Estonia (in particular, branches of foreign credit institutions) are required to include 50 percent of the total amount of loans secured by mortgages on residential property in the calculation of the base of the reserve requirement, unless the appropriate regulator applies a 100 percent risk weighting to all loans secured by mortgages on residential property granted to the 
residents of Estonia in the calculation of capital adequacy. Going forward, a practical constraint on using increases in risk weights in the EU member countries is that from January 2007, any increases must be consistent with the EU Capital Requirement Directive of Basel II, which substantially limits member countries' scope for discretion with respect to risk weights. The measure can still be useful in non-EU countries, such as Georgia, where the risk weights for unhedged foreign exchange loans have been recently increased to 200 percent, but the scope for their use in the EU is likely to be limited.

- Minimum prudential norms. Several countries (mostly the CEECs and in East Asia) recently introduced measures to limit the eligibility for loans. These measures included the requirement to deny loans to homeowners whose monthly payment exceeds a certain proportion of income (for example, 35 percent in Romania and 50 percent in China), a higher required down payment of property purchase price (25 percent in Romania and 30 percent in China), or a requirement that all mortgages be repaid before selling a home.

- Higher provisions and stricter loan classification. Higher general provisions for foreign currency loans have an impact similar to that of higher risk weights. Supervisors need to ensure that unhedged foreign currency loans that have turned bad are properly provisioned through specific provisions. In Romania, for example, the authorities have refined regulations on provisioning and loan classification to take the exchange rate risk of the borrower into account.

- $\quad$ Reserve requirements. For example, the Romanian authorities increased reserve requirements on foreign currency-denominated liabilities from 30 percent to 35 percent in December 2005, and again to 40 percent in February 2006, even though these measures may not have been motivated entirely by credit risk concerns, but also by more general macroeconomic considerations. In Estonia, the central bank increased the reserve requirement from 13 percent to 15 percent from September 1, 2006, aiming to curb the macroeconomic risks associated with the rapid growth of domestic demand and loans.

- $\quad$ Foreign exchange liquidity requirements. To manage aggregate foreign exchange liquidity mismatch on banks' balance sheets, Croatia introduced, and subsequently tightened, minimum requirements on foreign exchange liquidity held by banks against their foreign exchange liabilities. These measures limited the foreign exchange liquidity exposures in the banking system, but they had only a limited impact on lending (and capital inflows more generally) in the context of a foreign exchange regime aiming to preserve exchange rate stability.

- Ceilings on exposures. For example, the Romanian authorities introduced a ceiling on foreign exchange credit exposures arising from loans granted to unhedged individuals and legal persons (other than credit institutions) in the amount of 300 percent of own funds. The measure reduced the share of foreign currency loans in total loans and had limited effect on the rate of credit growth. These measures might have encouraged, however, a transfer of credit activity to the nonbank sector. 


\section{REFERENCES}

Black, F., and M. Scholes, 1973, "The Pricing of Options and Corporate Liabilities," Journal of Political Economy, Vol. 81, No. 3, 637-54.

Beck, Thorsten, and Luc Laeven, 2006, "Resolution of Failed Banks by Deposit Insurers: Cross-Country Evidence," mimeo (Washington: World Bank).

Coricelli, Fabrizio, and Igor Masten, 2004, "Growth and Volatility in Transition Countries: The Role of Credit," a paper presented at the IMF Conference in honor of Guillermo Calvo, April 15-16 2004.

Danmarks Nationalbank, 2004, "Market-Based Risk Measures for Banks," in Financial Stability 2004 (Copenhagen: Danmarks National Bank).

De Nicoló, Gianni, Robert Corker, Alexander F. Tieman, and Jan Willem van der Vossen, 2005, "European Financial Integration, Stability and Supervision," in IMF Country Report No. 05/266 (August), pp. 113-146 (Washington: International Monetary Fund).

Dell' Ariccia, Giovanni; Enrica Detragiache, and Raguram Rajan, 2005, "The Real Effect of Banking Crises," IMF Working Paper, 05/63 (Washington: International Monetary Fund).

European Bank for Reconstruction and Development, 2005, "The Impact of the Legal Framework on the Secured Credit Market in Poland" (Warsaw: National Bank of Poland).

Fitch Ratings, 2005a, "Polish Banks' Annual Review and Outlook-Ratings Upgrades Possible," June 7.

Fitch Ratings, 2005b, “Assessing Bank Systemic Risk: A New Product,” July 26.

Fitch Ratings, 2005c, “CEE Housing Finance: Rapid Growth, but at What Risk?” November 7.

Hilbers, Paul, Inci Otker-Robe, Ceyla Pazarbasioglu, and Gudrun Johnsen, 2005, “Assessing and Managing Rapid Credit Growth and the Role of Supervisory and Prudential Policies," IMF Working Paper 05/151 (Washington: International Monetary Fund).

International Monetary Fund, 2005a, “Austria-Financial Sector Stability Assessment (FSSA),” IMF Country Report No. 04/238 (August) (Washington: International Monetary Fund).

-, 2005b, "Hungary_Financial Sector Stability Assessment (FSSA)," IMF Country Report No. 05/212, June 2005 (Washington, DC: International Monetary Fund). 
King, Robert G. and Ross Levine, 1993, "Finance and Growth: Schumpeter Might be Right," The Quarterly Journal of Economics, Vol. 108, No. 3 (August), pp. 717-737.

Maechler, Andrea, Srobona Mitra, and DeLisle Worrell, 2005, "Exploring Financial Risks and Vulnerabilities in New and Potential EU Member States," Second Annual DG ECFIN Research Conference: "Financial Stability and the Convergence Process in Europe," October 6-7, 2005.

Merton, R.C., 1974, "On the Pricing of Corporate Debt: The Risk Structure of Interest Rates," Journal of Finance, Vol. 29, No. 2, pp. 449-70.

Moody’s Investor Service, 2005, “Banking System Outlook: Poland,” December.

National Bank of Poland, 2005, "Financial Stability Review," First Half of 2005 (Warsaw: National Bank of Poland).

National Bank of Poland, 2004, "Financial System Development in Poland 2002-2003" (Warsaw: National Bank of Poland).

National Bank of Poland, "Summary Evaluation of the Financial Situation of Polish Banks," various issues (Warsaw: National Bank of Poland).

Neir, Erlend, and Lea Zicchino, 2006, "Bank Weakness, Loan Supply and Monetary Policy," Bank of England, mimeo.

Rajan, Raguram, and Luigi Zingales, 1998, "Which Capitalism? Lessons from the East Asian Crisis," Journal of Applied Corporate Finance, Vol. 11, pp. 40-48.

World Bank, 2006, "Poland: Legal Barriers to Contract Enforcement," forthcoming (Washington, DC: World Bank). 